PontIFícIa UNIVERSIDADE CATÓLICA dO RIO DE JANEIRO

\title{
Geração Y e Âncoras de Carreira
}

Fernanda Magalhães de Souza Conti

Trabalho de Conclusão de Curso

Centro de ciências sociais - CCS

DEPARTAMENTO DE ADMINISTRAÇÃO

Graduação em Administração de Empresas 


\section{Fernanda Magalhães de Souza Conti}

\section{Geração Y e Âncoras de Carreira}

Trabalho de Conclusão de Curso

Trabalho de Conclusão de Curso, apresentado ao programa de graduação em Administração da PUC-Rio como requisito parcial para a obtenção do titulo de graduação em Administração.

Orientadora: Patrícia Ítala Ferreira

Rio de Janeiro, Novembro de 2016. 


\section{Agradecimentos}

Agradeço primeiramente aos meus pais, que humildemente, sempre se esforçaram para me dar um ensino de qualidade, que estiveram sempre do meu lado e que me ensinaram os valores da vida.

Aos meus familiares, que sempre me apoiam em minhas decisões e torcem por mim.

Às minhas amigas, pelas palavras de apoio e torcida, que sempre estiveram próximas e entenderam minha omissão em alguns momentos.

A todos os meus professores da PUC-Rio, que me passaram seus conhecimentos e ensinamentos e, sobretudo à minha orientadora Patricia ítala Ferreira, pela paciência, dedicação e ajuda, para a conclusão desta monografia. 


\section{Resumo}

Conti, Fernanda Magalhães de Souza, Ferreira, Patrícia Ítala. Geração Y e Âncoras de Carreira. Rio de Janeiro, 2016, 49 p. Trabalho Final de Curso - Disciplina Integradora IV Departamento de Administração. Pontifícia Universidade Católica do Rio de Janeiro.

O ambiente corporativo tem enfrentado diversas mudanças com a entrada da Geração Y no mercado de trabalho. Esta geração representa um grupo que possui expectativas e valores diferentes das demais. Diante disto, é importante verificar o que desejam em termo de carreira. 0 presente estudo possui o objetivo de identificar quais são os direcionadores das escolhas desses jovens profissionais considerando o conceito de âncoras de carreira, definido por Schein. E, para isso, foi realizada uma pesquisa de campo com os profissionais da Geração Y.

Palavras-chave: Geração Y; Carreira; Âncoras de Carreira

\section{Abstract}

Conti, Fernanda Magalhães de Souza, Ferreira, Patrícia Ítala. Generation $Y$ and Careers Anchors. Rio de Janeiro, 2016, 49 p. Trabalho Final de Curso - Disciplina Integradora IV Departamento de Administração. Pontifícia Universidade Católica do Rio de Janeiro

The corporate environment has faced several changes with the entry of Generation $Y$ in the labor market. This generation represents a group that has expectations and values different from the others. In view of this, it is important to check what they want in terms of career. The present study has the objective of identifying what are the directors of the choices these young professionals considering the concept of career anchors, defined by Schein. And,for this reason, it was conducted a research survey with professionals of Generation Y.

Key-words: Generation Y; Career; Careers Anchors. 


\section{Sumário}

1 O tema e o problema de estudo 1

1.1. Introdução ao tema e ao problema do estudo 1

1.2. Objetivo do estudo 2

1.3. Objetivos intermediários do estudo 2

1.4. Delimitação e foco do estudo 3

1.5. Justificativa e relevância do estudo 3

2 Referencial teórico 5

2.1. O conceito de carreira 5

2.1.1. A evolução do conceito de carreira $\quad 7$

2.2. As âncoras de carreira 8

2.3. Conceituando as gerações 11

2.3.1. Baby Boomers 12

2.3.2. Geração X 13

2.3.3. Geração $Y \quad 14$

2.4. Geração $Y$ no ambiente de trabalho 15

3 Métodos e procedimentos de coleta e de análise de dados do estudo 18

$\begin{array}{ll}3.1 . & \text { Tipo de pesquisa utilizada } \\ & 18\end{array}$

3.2. Universo e amostra 18

3.3. Procedimentos e instrumentos de coleta de dados utilizados no $\begin{array}{ll}\text { estudo } & 19\end{array}$

3.4. Procedimento de análise dos dados 19

$\begin{array}{ll}\text { 3.5. Limitações do estudo } & 20\end{array}$

4 Descrição e análise dos resultados $\quad 21$

4.1. Perfil dos participantes 21

4.2. Perfil profissional dos participantes 26

4.3. Âncoras de carreira 29 
5 Conclusão

\section{Lista de Figuras}

Figura 1: Principais fases da carreira 6

\section{Lista de Tabelas}

Tabela 1: Características dos grupos geracionais...................................16

Tabela 2: Ética profissional e Geração Y...............................................21

Tabela 3: Idade relativa de moradia com pai e/ou mãe...........................27

Tabela 4: Locais cursados no Ensino Superior.......................................30

Tabela 5: Motivos de saída da empresa................................................33

Tabela 6: Primeira âncora de carreira....................................................34

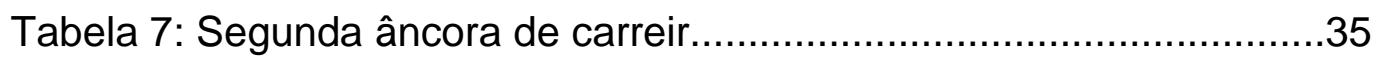

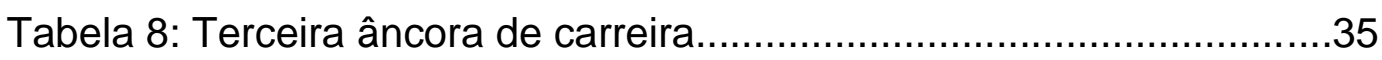

Tabela 9: Classes sociais e suas principais âncoras................................36

Tabela 10: Resultado: âncoras de carreira................................................37

Tabela 11: Posições da primeira âncora de carreira................................38 


\section{Lista de Gráficos}

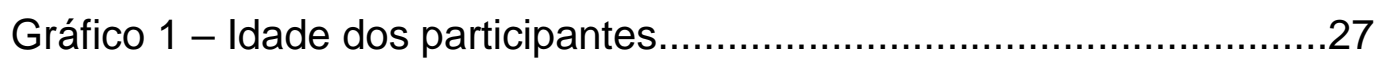

Gráfico 2 - Sexo dos participantes.................................................28

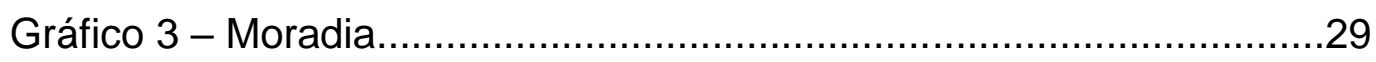

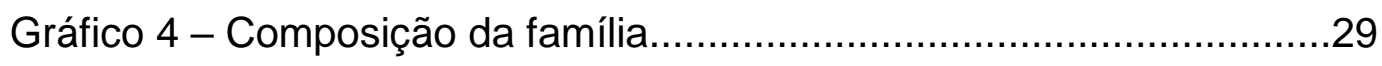

Gráfico 5 - Composição da família.....................................................30

Gráfico 6 - Grau de escolaridade......................................................

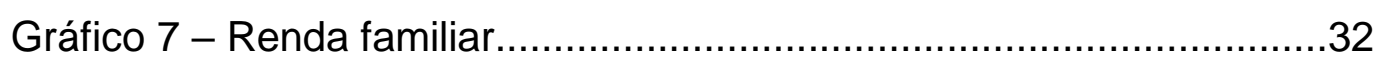

Gráfico 8 - Quantidade de empresas trabalhadas..................................33

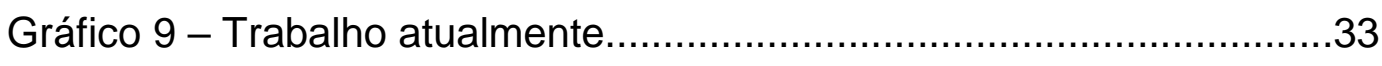

Gráfico 10 - Fazer carreira na empresa atual.......................................34 


\section{0 tema e o problema de estudo}

\subsection{Introdução ao tema e ao problema do estudo}

Atualmente, pode-se perceber diversas gerações atuando juntas em um mesmo ambiente corporativo, e cada uma com suas particularidades. Segundo Oliveira (2009), a definição de geração é dada pela idade cronológica e o cenário social, político e econômico em que se encontram. A diferença do marco de separação de uma geração para a outra é de 20 anos. A mais nova, aquela que tem se inserido no ambiente de trabalho, é a chamada Geração $Y$, que abrange os jovens que nasceram de 1978 a 1998, por Veloso et al (2008).

O que diferencia as gerações são suas experiências e visões de mundo a partir dos fatores externos, como o ambiente e época em que vivem, de acordo com Oliveira (2009). Mesmo compreendendo as diferenças e sabendo lidar com diversas gerações, as empresas não têm certeza sobre quais políticas e metodologias devem ser aplicadas para manter os jovens fiéis a elas.

Os $Y$ nasceram em uma época tecnológica e foram bastante protegidos por seus pais. São autoconfiantes e seguros de si, segundo Lipkin e Perrymore (2010). Priorizam as questões pessoais às profissionais e acreditam que o trabalho é uma fonte de satisfação e aprendizado, não servindo apenas para fins de sustento. São também ligados à responsabilidade social, o que ainda não está presente em muitas organizações (VELOSO et al., 2008). Possuem um perfil muito independente, procurando sempre o equilíbrio entre a vida pessoal e a profissional (TULGAN, 2009).

Para entender melhor estes jovens, deve-se observar os tipos de carreiras que, para diversos autores tem um significado diferente. A evolução deste conceito se deu pelas mudanças de relação de empregador-empregado, já que as organizações sofreram transformações 
e reestruturações com o tempo. Há dois modelos de carreiras diferentes. A primeira é a carreira sem fronteira, definida por Arthur e Rousseau (1996) e a segunda é a carreira proteana, descrita por Hall (2002).

Em 1978, Schein apresentou oito âncoras de carreiras, que representam suas inclinações profissionais, o verdadeiro "eu" do indivíduo. Funcionam como referenciais já pré-estabelecidos pelas pessoas ao fazerem escolhas baseadas em seus talentos, motivos, competências, habilidades, necessidades e valores. São eles: Competência Gerencial Geral, Segurança/Estabilidade, Competência Técnico-Funcional, Autonomia/Independência, Criatividade Empresarial, Serviço e Dedicação a uma causa, Desafio Puro e Estilo de Vida.

O presente trabalho tem como objetivo compreender o que os profissionais da Geração $Y$ desejam em termos de carreira, considerando o conceito de âncoras de carreiras descrito por Schein (1996). Deve-se, portanto, pôr em evidência a seguinte questão: o que buscam os jovens $\mathrm{Y}$, considerando as âncoras de carreira?

\subsection{Objetivo do estudo}

Este trabalho tem como objetivo identificar os principais direcionadores das escolhas profissionais dos jovens da geração $Y$, que já trabalharam e/ou trabalham atualmente, considerando a descrição de âncoras de carreira, determinadas por Schein (1996).

\subsection{Objetivos intermediários do estudo}

Para se atingir o objetivo final proposto, este estudo prevê, como objetivos intermediários a serem alcançados:

- Levantar, descrever e comparar os modelos de carreiras e as principais características e motivações das gerações, com foco na geração $\mathrm{Y}$;

- Apresentar os conceitos relacionados às âncoras de carreira;

- Realizar uma pesquisa de campo junto aos jovens da Geração Y; 
- Investigar se as âncoras são semelhantes para os jovens da Geração Y.

\subsection{Delimitação e foco do estudo}

Delimita-se esse estudo à identificação das âncoras de carreira praticadas e reconhecidas como fator relevante pela Geração Y, considerando as definições descritas por Schein (1996).

O estudo restringiu-se aos jovens nascidos a partir de 1978 até 1998, que estão a faixa etária da geração Y segundo Veloso et al (2008). Foram considerados homens e mulheres que já atuaram pelo menos uma vez no mercado de trabalho, sendo ainda estudantes ou não de diferentes instituições de ensino do Estado do Rio de Janeiro e de diversas classes sociais. A pesquisa foi aplicada em novembro de 2016 por meio de um questionário que também continha o teste de âncoras de carreira de Schein (1996).

\subsection{Justificativa e relevância do estudo}

O desafio para muitos gestores atualmente é de manter e saber lidar com os empregados da Geração $Y$, por diversas questões que os caracterizam no ambiente corporativo, de acordo com Lipkin e Perrymore (2010).

Esse trabalho é relevante para os profissionais que trabalham junto aos jovens da Geração $\mathrm{Y}$, para que possam entender seus perfis ancorados por características singulares e próprias e que aprendam a lidar com essa geração no mesmo ambiente corporativo. Também para que consigam, atraí-los para o mercado de trabalho com a maior probabilidade que o perfil da empresa seja adequado com o perfil do indivíduo, em termos aspiracionais.

Há relevância também para os próprios integrantes da Geração $Y$ para ajuda-los na melhor compreensão de seu perfil profissional e na 
definição de suas prioridades no ambiente de trabalho, buscando organizações que atendam, minimamente, seus requisitos e prioridades.

O estudo é importante também para a academia, professores e pesquisadores, que procuram entender os principais direcionadores dessa geração e suas possíveis âncoras de carreira, demonstrando pouca diferença de perfis profissionais entre indivíduos de diferentes classes sociais. 


\section{Referencial teórico}

\subsection{O conceito de carreira}

De acordo com Hall (2002, apud COSTA 2010), existem vários significados para carreira:

- Como um avanço: é a visão entendida pela maioria, como a mobilização vertical nas hierarquias a partir de promoções.

- Como profissão: ocupações que são submetidas aos movimentos de status (por exemplo: carreira docente, militar), diferente dos demais que são considerados como "construção de carreiras".

- Como sequência de trabalhos no decorrer da vida profissional: histórico de trabalho junto com os respectivos cargos e posições ocupadas de uma pessoa.

- Como sequência de experiências ao longo da vida: amadurecimentos ao longo do histórico de vida independentemente se exerceram ou não atividades profissionais.

Bergamini (2014) afirma que a escolha de uma carreira deve ser feita a partir da combinação de características pessoais e os valores de vida.

Para Schein (1996), a palavra carreira pode ter diversos significados e segundo ele,

É constituída de várias e significativas unidades ou fases, reconhecidas pela pessoa e pela sociedade, embora 0 espaço de tempo associado a cada uma delas varie muito de acordo com a profissão ou com a pessoa que a exerce (SCHEIN, 1996, p. 20).

De acordo com o autor, existem dois modelos de carreira: a interna, que significa como o indivíduo vê sua própria vida profissional, do seu próprio ponto de vista e a externa, que se desenvolve através de 10 
fases apontadas pela sociedade e exigidas pelas organizações. A duração de cada fase varia de uma pessoa para outra e não se relaciona com a faixa etária obrigatoriamente. São elas:

Figura 1: Principais fases da carreira

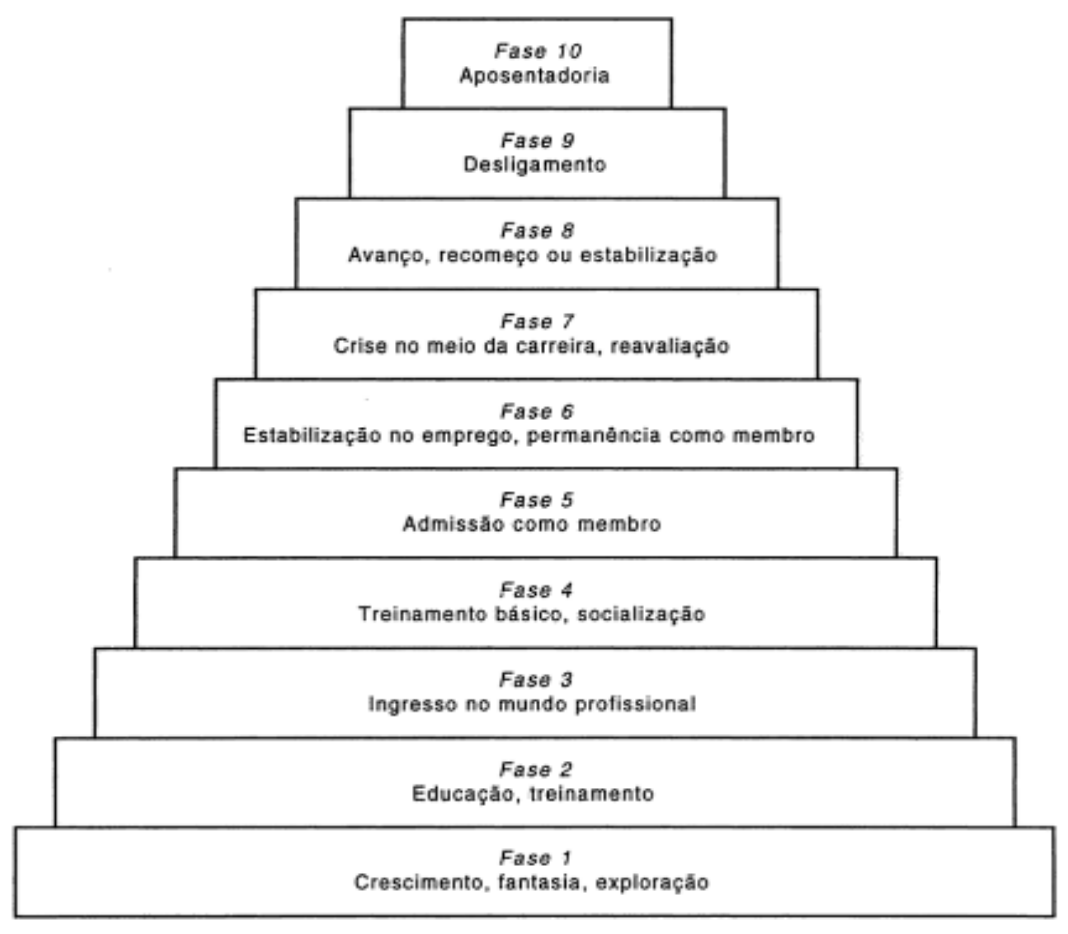

Fonte: Schein (1996, p.21)

A fase 1 , que é a base, representa o período da infância à préadolescência, é a fase de preparação para o processo educacional. Não há uma definição certa de profissão ainda. Já a fase 2 tem a educação e treinamento para escolher os ofícios. Ela depende da profissão escolhida e as metas e duração variam de acordo com as escolhas feitas.

$\mathrm{Na}$ fase 3 mostra-se o período de adaptação na qual os indivíduos compreendem a realidade do trabalho e suas reações. É o início do aprendizado pessoal e evolução do seu próprio conceito de profissional, tendo assim a continuação na fase 4 , em que o indivíduo deve fazer uma escolha concreta quanto à continuação na profissão/organização mediante as exigências da empresa.

$\mathrm{Na}$ fase 5, tem-se o reconhecimento da ultrapassagem da fase de treinamento e surgimento da auto-imagem como profissional efetivo. Há a percepção de suas aptidões, objetivos, pontos fortes e fracos. Após isso, a organização decide se o profissional se manterá ainda no trabalho ou se 
o dispensará, de acordo com o tempo de permanência, sendo mais uma etapa, fase 6.

A fase 7 costuma ser o período de crise do indivíduo na carreira acompanhado com um processo de reavaliação da escolha profissional, podendo acontecer ou não essa crise. O resultado de sua reavaliação leva como decisão a continuação ou não da carreira escolhida, que constitui a fase 8 .

Por fim, na fase 9 o indivíduo desacelera o ritmo de produção, tem menor envolvimento e já começa a pensar na aposentadoria. E sua última fase, a aposentadoria pode ser considerada um fator bom ou ruim, já que para alguns remete a perda de saúde física ou mental e para outros, pois desejam começar outras carreiras ou a instituição os incentiva.

A partir dessas descrições, serão avaliadas, na sequência, a evolução e as características das teorias de carreira, propostos por alguns autores.

\subsubsection{A evolução do conceito de carreira}

A partir dos anos 80, as organizações sofreram transformações e reestruturações, como por exemplo, downsizing, fusões e aquisições. Com estas mudanças de relações de empregado-empregador, alguns autores criaram teorias de carreiras emergentes, contemporâneas, como por exemplo: carreira sem fronteira (ARTHUR e ROUSSEAU,1996) e carreira proteana (HALL, 2002).

Segundo Arthur e Rousseau (1996), o conceito de carreira sem fronteira se dá por serem mais abertas, menos controladas e diversificadas. Essa concepção ocorre quando a carreira ultrapassa 0 limite de um único empregador, o que pode alterar alguns vínculos empregatícios e, até mesmo, as ocupações. Os indivíduos passam a ser responsáveis pela sua própria gestão de carreiras, buscando ocasiões que Ihes possibilitem manter ou até aumentar sua empregabilidade.

O gerenciamento desse tipo de carreira demandam algumas habilidades, diferente do que era requisitado no passado. É um conjunto 
de elementos que caracterizam "carreiras inteligentes", proposto por Arthur e Rousseau (1996). São eles: (1) saber porque: atitudes, valores, estilo de vida, necessidade interna e identidade; (2) saber como: habilidades, conhecimento explícito e tácito, competências e experiências; (3) saber quem: como se relacionar com as pessoas certas

Na carreira proteana, o indivíduo também está no controle e não a organização, já que, as decisões de carreira cabem aos profissionais. Consiste da somatória de várias experiências com empregos, educação, treinamento, mudanças das atividades, etc. Procura ter a auto-realização integrando as escolhas pessoais. Para ele, o sucesso não é externo, mas sim interno (sucesso psicológico) (HALL; MOSS, 1998).

Ainda segundo Hall (2002), apesar de ser o mais democrático, esse modelo tem as características de instabilidade, descontinuidade e horizontalidade. A mudança de carreiras (do tradicional para o proteano) não significou de fato um progresso e bem-estar para os indivíduos que se tornaram responsáveis pelas suas carreiras.

Para Briscoe et al.(2006), a carreira proteana é caracterizada pela liberdade, pela autonomia de auto-gerenciar e pelas escolhas feitas com base nos valores pessoais. Com essa forma de carreira, tem-se 0 crescimento horizontal para expansão de competências e novos trabalhos e relacionamentos, uma vez que ela é composta de miniestágios e/ou pequenos ciclos entre áreas, funções ou organizações (BALASSIANO; VENTURA; FONTES FILHO, 2004).

No ítem a seguir, serão abordados os conceitos de âncora de carreira, descrito por Schein (1996), que constará como referência para a pesquisa desse trabalho na classificação profissional do indivíduo.

\subsection{As âncoras de carreira}

Segundo Schein (1996), com a globalização, diversificação e as novas tecnologias avançando, o mercado de trabalho é mais propício para diferentes escolhas de carreira, o que acaba sendo um desafio para algumas organizações, já que o profissional se torna mais individualista, 
começa a focar em autodesenvolvimento e programar a carreira em razão dos próprios desejos e necessidades. Diferente de antigamente em que se tinha uma relação de longo prazo com as instituições que conseguiam fazer a gestão de carreira do indivíduo (BALASSIANO e COSTA, 2006);

A partir de um estudo longitudinal com 44 alunos da Sloan School of Management de Massachusetts Institute of Technology (MIT), Schein conseguiu definir algumas inclinações profissionais em oito categorias de âncoras de carreira a partir de suas características e padrões de escolha. Para o autor, a âncora de carreira representa o verdadeiro "eu" do profissional, o que o move mesmo quando precisa decidir entre escolhas difíceis e na auto percepção de seus talentos, valores, habilidades e necessidades (SCHEIN 1996; MELO 2010). Para Kilimnik et al (2007), âncoras de carreira são percebidas pelo indivíduo a partir das experiências já tidas ao longo de sua trajetória profissional, pela sua identificação de padrões de ambição, pela geração de critérios e pelo sucesso que a pessoa define para si mesma.

Inicialmente foram identificadas cinco tipos de âncoras: competência técnica, competência gerencial geral, autonomia/independência, segurança/estabilidade e criatividade empreendedora. No final da década de 70, Schein (1978) uniu mais três categorias (serviço e dedicação a uma causa, puro desafio e estilo de vida). Serão apresentadas, na sequência, as oito âncoras que foram identificadas pelo autor:

1. Competência Técnica-Funcional (TF) - Caracterizam profissionais que priorizam a aplicação de seus conhecimentos e habilidades técnicas. São indivíduos que valorizam a especialização em uma área específica e buscam desafios que provoquem seus conhecimentos. Preferem o reconhecimento como especialista ao ter promoções para alguma área de gestão que o tire da sua sabedoria técnica.

2. Competência Gerencial Geral (GG) - Os profissionais ancorados nesta categoria são motivados por subir na hierarquia da empresa, ter oportunidade de liderar, sentindo necessidade de conhecer várias áreas. Identificam-se muito com a organização e 
estabelecem contratos psicológicos, compreendendo que 0 sucesso da empresa é o seu próprio sucesso.

3. Autonomia e Independência (AI) - Esse grupo possui profissionais que não toleram bem as regras, normas, procedimentos e controles dados por terceiros. Gostam de ter autonomia para trabalharem no ritmo e à maneira que querem. Preferem buscar carreiras mais independentes, como profissionais liberais, professores, consultores, etc.

4. Segurança e Estabilidade (SE) - Estes profissionais prezam pela sua segurança financeira e estabilidade na empresa, sendo seus principais pilares para decisão de carreira. As motivações destes profissionais são os aumentos salariais, benefícios que tenham programa de seguro e aposentadoria e boas condições de trabalho.

5. Criatividade Empreendedora (CE) - Neste grupo, os indivíduos são motivados a criar seu próprio negócio e julgam seu sucesso pela capacidade de gerar dinheiro. Ficam entediados facilmente se não estiverem envolvidos com trabalhos que desafiem sua criatividade e não costumam trabalhar em empresas tradicionais.

6. Serviço ou Dedicação a uma Causa (SD) - As pessoas dessa âncora de carreira são atraídas por uma causa humanitária, voltadas para criar um mundo melhor. Seus valores pessoais são fundamentais em seu trabalho, mesmo que tenham que abdicar a exercer atividades relacionadas a suas competências ou talentos. Buscam o reconhecimento de seus superiores e não valorizam muito o dinheiro, desde que ele seja considerado justo.

7. Desafio Puro (DP) - Esses profissionais buscam sempre maiores desafios para eles, seu sucesso é superá-los. São pessoas muito competitivas e que se entediam facilmente com situações de mesmice e falta de variedade, desmotivando-se pela ausência de desafios.

8. Estilo de Vida (EV) - Os profissionais desse grupo procuram integrar suas próprias necessidades com as da família e da vida profissional. Estão dispostos a trabalharem em organizações que 
são de acordo com suas vontades, como horário flexível, permitindo home-office e jornada de meio período.

Para Melo (2010), as formas como as pessoas agem para alcançar os objetivos pessoais são refletidas pelos seus comportamentos para a construção de carreira de sucesso, apesar de ter significados e visões diferentes com o passar do tempo para esses indivíduos.

No tópico abaixo, serão exibidas as características das gerações com enfoque na Geração Y, que será uma das bases para pesquisa.

\subsection{Conceituando as gerações}

Segundo Kupperschmidt (2000 apud Wong et al. 2008), uma geração é definida como um grupo de indivíduos que nascem em um mesmo período e que compartilham etapas críticas de desenvolvimento e importantes e significativos eventos que acontecem durante esse período. Já para Smola e Sutton (2002), são pessoas que nascem em uma mesma época e passam pelas mesmas mudanças sociais e políticas, que podem afetar o padrão de resposta a certas situações, como seus valores, comportamentos, ética, motivações e aspirações de maneiras parecidas.

A tabela 1 apresenta as principais características dos grupos geracionais:

Tabela 1: Características dos grupos geracionais

\begin{tabular}{|c|c|}
\hline $\begin{array}{c}\text { Grupo } \\
\text { Geracional }\end{array}$ & Características \\
\hline $\begin{array}{c}\text { Baby } \\
\text { Boomers }\end{array}$ & $\begin{array}{c}\text { São workaholics, valorizam o status e ascensão } \\
\text { profissional dentro da empresa, a qual são leais. São } \\
\text { idealistas e motivados. }\end{array}$ \\
\hline Geração X & $\begin{array}{c}\text { São céticos e defendem um ambiente de } \\
\text { trabalho com menos hierarquias e mais informal; São } \\
\text { autoconfiantes, porém após o aumento de turnover } \\
\text { nas empresas, passaram a valorizar sua } \\
\text { empregabilidade. }\end{array}$ \\
\hline
\end{tabular}




\begin{tabular}{|c|c|}
\hline $\begin{array}{c}\text { Grupo } \\
\text { Geracional }\end{array}$ & Características \\
\hline Geração Y & $\begin{array}{c}\text { Mais individualistas, e trabalham para um mundo } \\
\text { melhor. Defendem suas opiniões e buscam prazer no } \\
\text { que fazem. Priorizam mais o lado pessoal às questões } \\
\text { profissionais }\end{array}$ \\
\hline
\end{tabular}

Fonte: Adaptado de Veloso et al. (2008)

Apesar da literatura não definir de forma consensual as datas de cada geração, as características de cada uma não mudam significativamente. Para esse estudo utilizou-se uma base para as gerações, de acordo com Veloso et al. (2008):

- Baby Boomers: Nascidos entre 1946 e 1964;

- Geração X: Nascidos entre 1965 e 1977;

- Geração Y: Nascidos entre 1978 e 1998.

Serão exploradas, na sequência, as principais características de cada geração.

\subsubsection{Baby Boomers}

De acordo com Oliveira (2010), os baby boomers nasceram no período de 1946 a 1964, a época do pós-guerra. Esse contexto influenciou muito as características dessa geração, já que a sociedade estava sendo reconstruída rapidamente com uma alta taxa de natalidade, em fator da economia que se encontrava forte e estável (SOLOMON, 2015). Vivenciaram o nascimento do rock and roll, Woodstock e a guerra do Vietnã, os quais foram fatores que influenciaram essa geração. A educação foi feita baseada em acatar a disciplina nos estudos e no trabalho e a respeitar os valores familiares, com obediência e ordem (OLIVEIRA, 2010).

Segundo o autor, os Boomers podiam ser classificados de duas formas: o rebelde e o disciplinado. O rebelde é utilizado para classificar pessoas muito influenciadas pelas músicas e cinema da época. Não se preocupavam em ter um futuro estruturado e tinham comportamentos desobedientes. Já os disciplinados eram jovens que apresentavam comportamentos obedientes às autoridades e cresceram esperando 0 
melhor da vida, valorizando os cargos para trabalhar e os destaques que ganhava. Conforme Twenge e Campbell (2008), essa geração pode ser descrita por um perfil mais individualista de forma moderada.

Eles são profissionais que valorizam a estabilidade no trabalho, satisfação pessoal, interessados pelo poder, status e ascensão profissional, fazendo carreira na mesma empresa e têm dificuldade em conciliar a vida profissional com a pessoal por serem considerados uma geração de workaholics (TULGAN, 2009; SMOLA; SUTTON, 2002).

Para Melo (2010), a grande maioria está aposentada atualmente, e uma parte se encontra em altos cargos nas hierarquias das organizações e/ou atuam como executivos. Um movimento importante é a saída desses profissionais e a entrada da geração $\mathrm{X}$, com características bem distintas da geração anterior.

\subsubsection{Geração $X$}

A geração após os Baby Boomers nasceu em uma época de mudanças culturais como o assassinato e saída de vários líderes políticos, como por exemplo, Malcom X, Martin Luther King e a renúncia de Richard Nixon; corrida armamentista e período de Guerra Fria. Isso acarretou um maior ceticismo, por conta das e vulnerabilidade das autoridades, o que levou aos pais se oporem contra qualquer coisa com aspecto padronizado ou convencional, incluindo a estrutura familiar. (OLIVEIRA, 2010). Nesse mesmo momento, no Brasil, acontecia a ditadura extremamente agressiva, o que levou a perseguições à qualquer pessoa que resolvesse criticar as imposições feitas pelo governo. Os movimentos hippies e revoltas estudantis começaram a fazer parte desse panorama mundial (MELO; LEMOS; OLIVEIRA, 2010).

Ainda de acordo com Oliveira (2010), ao chegarem à vida adulta, os jovens da Geração X não se identificavam com a hostilidade dos movimentos políticos revolucionários. E suas características vieram daí: preferiam ser mais cuidadosos a oferecer riscos à família, sendo mais passivos às regras estabelecidas; autossuficientes, que levavam a priorização do trabalho; pragmáticos; egocêntricos e autoconfiantes. 
Segundo Tulgan (2009), as pessoas dessa geração valorizaram desenvolver habilidades que melhorassem sua empregabilidade, pois vivenciaram a era dos downsizings corporativos, que afetavam sua estabilidade no emprego. Buscavam frequentemente o feedback e estariam interessados em ganhos de oportunidades e recompensas, preocupando-se com objetivos particulares e o equilíbrio entre a vida profissional e pessoal (SMOLA; SUTTON, 2002; e WONG et al, 2008).

As pessoas da Geração $X$ foram os iniciadores das mudanças de ambiente na qual a Geração $Y$ está exposta, e que será detalhada no ítem a seguir.

\subsubsection{Geração $Y$}

A geração $\mathrm{Y}$, também conhecida como Millennials, Geração da Internet e iGeração é a parcela mais jovem que está atuando hoje no mercado de trabalho (LIPKIN, PERRYMORE; MELO, 2010). Os momentos que definiram as experiências dessa geração foram 0 desenvolvimento da tecnologia computacional e sua expansão da Internet com sites de relacionamento e simulação dos jogos virtuais de web-based e console (SMOLA; SUTTON, 2002; ALSOP, 2008; TULGAN, 2009).

Filhos dos Baby Boomers e da Geração X, nasceram em uma sociedade que se preocupava com segurança, com uma cultura focada nos filhos. Eram filhos desejados e protegidos, sendo alegres, seguros de si e cheios de energia. Estão em um contexto político que não teve muitas transformações, de acordo com Lipkin e Perrymore (2010).

Segundo Oliveira (2009), estes jovens estão acostumados com modelos familiares e educativos mais flexíveis, pois é comum ter pais separados e irmãos de outros pais ou mães diferentes. Possuem diversas influências de outros familiares, pois muitos foram criados por avós ou tios, devido aos pais que precisavam trabalhar, havendo uma maior autonomia da mulher, sendo mais independente emocional e financeiramente. Para compensarem essa ausência, estes pais ofereciam 
à seus filhos as melhores opções de escola e cursos extraclasses, como de inglês, informática e esportes.

Conforme Lipkin e Perrymore (2010), os Millennials possuem algumas características expressivas e diferentes das outras gerações. Apresentam um nível grande de autoestima, pois Ihes foi dito que podiam ser e fazer o que quiserem. Os pais os criaram de uma forma com premiações por quaisquer feitos, adquirindo assim uma grande autoconfiança, o que no futuro profissional os prejudicaria, por causa de limitações do ambiente de trabalho e a autoestima do jovem (SMOLA; SUTTON, 2002 e LIPKIN; PERRYMORE, 2010).

Essa geração prioriza as questões pessoais às questões profissionais, defendem suas opiniões e são mais individualistas. Procuram sempre um reconhecimento, feedback e equilíbrio entre a vida pessoal e profissional. Para eles, o que importa é o resultado e não os processos que ocorrem, não tendo assim muita paciência e buscam as coisas para agora (TULGAN, 2009). Apesar de almejarem a riqueza, são extremamente altruístas e se preocupam com as questões socioambientais do mundo (ALSOP, 2008).

Para as autoras Lipkin e Perrymore (2010), a visão socialmente responsável desses jovens contribuiu para uma tendência de fazerem trabalho voluntário ou serem admitidos por uma organização que preze esse fator de ocupação social, diferente das outras gerações. Devido à essa consciência, esses jovens exigem mudanças na cultura corporativa, para que incluam essa responsabilidade socioambiental em seus ofícios.

\subsection{Geração Y no ambiente de trabalho}

Atualmente, os jovens que procuram por uma nova profissão estão passando por momentos de descobertas e autoconhecimento, já que precisam passar por uma fase de escolhas, onde se necessita a distinção sobre o que querem e o que não querem. Para se diferenciar no mercado é preciso estar qualificado em uma área específica, tendo assim a 
escolha de sua carreira voltada para satisfação pessoal (DETONI; MARTINS; HARTMANN, 2012).

Se diferenciando das gerações anteriores, cujas vestimentas no ambiente de trabalho eram associadas às próprias capacidades e habilidades, a Geração $Y$ inova com um jeito mais informal nas roupas, o qual representa flexibilidade e conveniência nos comportamentos. $E$ essas atitudes convêm em suas roupas, assim como nos horários ou ambientes de trabalho, de acordo com Oliveira (2010).

Para Lipkin e Perrymore (2010), as características educativas dessa geração, que lhes foram passadas de seus pais, afetam totalmente seu jeito profissional. Por exemplo, possuem dificuldade em aceitar o fracasso, feedbacks negativos e críticas construtivas, assim como de ver outros pontos de vista, de reconhecer suas próprias limitações, de focar o presente, de assumir as responsabilidades por seus atos, etc.

A ética profissional da Geração $Y$ é bem diferente das normas, regras e filosofia que as empresas tradicionais prezam. Por causa disso, a tensão entre os funcionários de diversas gerações na empresa tem aumentado, já que os "novatos" começam a assumir o controle e os "tradicionais" se rendem à pressão. A tabela abaixo mostra suas diferenças de ética profissional.

Tabela 2: Ética profissional e Geração Y

\begin{tabular}{|c|c|}
\hline Ética profissional tradicional & Ética profissional da Geração $Y$ \\
\hline O trabalho em primeiro lugar & A vida em primeiro lugar \\
\hline $\begin{array}{l}\text { Distinção entre horário de } \\
\text { trabalho e horário de lazer }\end{array}$ & $\begin{array}{c}\text { Indistinção entre horário de } \\
\text { trabalho e horário de lazer = } \\
\text { integração vida profissional/vida } \\
\text { pessoal }\end{array}$ \\
\hline Segue regras acima de tudo & $\begin{array}{l}\text { Segue regras que funcionam e } \\
\text { estabelecem as próprias regras }\end{array}$ \\
\hline O chefe merece respeito & Respeito só quando merecido \\
\hline Tempo de serviço = promoção & Talento = promoção \\
\hline $\begin{array}{l}\text { Expediente das } 9 \mathrm{~h} \text { às } 18 \mathrm{~h}, \\
\text { com horas extras }\end{array}$ & Horário de trabalho indefinido \\
\hline Trabalho baseado em horas & $\begin{array}{l}\text { Quando terminar o trabalho, } \\
\text { posso ir embora, mesmo que seja } \\
\text { antes das } 18 \mathrm{~h}\end{array}$ \\
\hline
\end{tabular}




\begin{tabular}{|c|c|}
\hline Ética profissional tradicional & Ética profissional da Geração Y \\
\hline $\begin{array}{c}\text { Preferência por contato } \\
\text { pessoal }\end{array}$ & $\begin{array}{c}\text { Preferência por contato virtual } \\
\text { Veste sempre a camisa }\end{array}$ \\
\hline $\begin{array}{c}\text { Veste a camisa quando } \\
\text { necessário }\end{array}$ \\
nuda de acordo com as & $\begin{array}{c}\text { Espera que a empresa mude } \\
\text { de acordo com suas necessidades }\end{array}$ \\
\hline
\end{tabular}

Esse grupo é movido por desafios novos e exigem a autonomia de suas opiniões e atuações. Diferente das outras gerações, os $Y$ não se importam muito com a questão de promoção, entretanto se motivam com novas posições hierárquicas, não representando o poder, mas sim 0 reconhecimento que possuem e maior possibilidade de colocar em prática suas iniciativas (SILVA, 2011). 


\section{Métodos e procedimentos de coleta e de análise de dados do estudo}

\subsection{Tipo de pesquisa utilizada}

O tipo de pesquisa utilizada para o trabalho foi a pesquisa descritiva, pois, segundo Vergara (2006), busca a resolução de problemas por meio da análise, observação e descrição objetiva. São expostas as características de uma determinada população ou fenômeno.

Foi utilizado um questionário desenvolvido no Qualtrics, Os procedimentos técnicos utilizados foram bibliográfico e pesquisa de campo. Segundo Vergara (2006), trata-se de uma pesquisa bibliográfica porque teve como base material publicado em livros, jornais, revistas, sites e de uma pesquisa de campo em que se pode realizar uma investigação no local, que oferece elementos para observar e realizar a pesquisa a partir deles.

\subsection{Universo e amostra}

O universo da pesquisa consistiu em jovens de 18 a 38 anos (nascidos entre 1978 e 1998), cuja faixa etária corresponde à Geração Y que estudaram no Estado do Rio de Janeiro, considerando somente aqueles que já estagiaram ou trabalharam em pelo menos alguma organização.

Foi utilizada uma amostra não probabilística por acessibilidade, também conhecida como por conveniência, que de acordo com Gil (2007), é de fácil acesso ao pesquisador não tendo como base nenhum fundamento estatístico ou matemático. Contou-se com um total de 95 respostas válidas. 


\subsection{Procedimentos e instrumentos de coleta de dados utilizados no estudo}

Como instrumento de coleta, foi utilizado um questionário feito no software Qualtrics, que segue no Apêndice 1.

O questionário apresentou o teste de âncoras de carreiras de Schein (1996) junto com perguntas fechadas. Primeiramente, foi feito um questionário teste com três pessoas para fins de entendimento, adequação e verificação de clareza das questões e da pesquisa. Após 0 teste, o questionário foi revisto e dividido em três partes. A primeira possuía duas perguntas filtros: idade e se já havia trabalhado, por conta do objetivo do estudo. Quem não se enquadrava no perfil era direcionado para a tela final e o questionário se encerrava. A segunda parte foi 0 Inventário de Âncoras de Carreira de Schein (1996), composto por 40 questões que identificam as âncoras de cada indivíduo dentre as oito categorias possíveis. E, por fim, a terceira parte se deu por 12 perguntas pessoais fechadas com filtros na questão em relação a ter já trabalhado e ao nível de escolaridade.

No bloco sobre as Âncoras de Carreira, foi solicitado aos respondentes que atribuíssem de 1 a 6 pontos para cada uma das quarenta afirmações propostas, sendo 1 "nunca verdadeiro pra mim", 2 e 3 "ocasionalmente verdadeiro" com menor e maior intensidade, 4 e 5 "frequentemente verdadeiro" com menor e maior intensidade e 6 "sempre verdadeiro pra mim". Após a numeração, foi requerido que se escolhesse três afirmações que consideravam mais importantes dentre as respostas dadas com números 5 ou 6 .

A coleta de dados se deu pelo envio do link do questionário para o público alvo (Geração Y) via redes sociais e e-mail, com o objetivo de conseguir alcançar um maior número de respondentes.

\subsection{Procedimento de análise dos dados}

De acordo com Vergara (2004), o tratamento dos dados pode ocorrer de duas formas: quantitativa e/ou qualitativa. A primeira é por 
meio dos procedimentos estatísticos e a segunda é feita pela codificação e análise mais profunda dos dados. Ambas podem ser utilizadas juntas.

O tratamento foi feito de forma quantitativa e qualitativa, considerando o referencial teórico e gerando gráficos e tabelas.

Para a análise do modelo de Âncoras de Carreira de Schein (1996), a autora aplicou mais 4 pontos sobre as três afirmações escolhidas entre 5 e 6, para proporcionar uma maior percepção sobre sua possível categoria de âncora. Após essa etapa, as pontuações foram separadas em grupos por âncoras a partir da soma dos números atribuídos pelos respondentes nas 40 questões e, com isso, foram identificadas as três âncoras que obtiveram maior valor para classificar o seu perfil profissional.

\subsection{Limitações do estudo}

Esse estudo buscou comparar as âncoras de carreira dos indivíduos da Geração Y, contudo, o trabalho possui algumas limitações que serão vistas abaixo.

Segundo Gil (2007), a utilização do questionário aborda poucas perguntas, uma vez que se muito extenso, há a probabilidade de não serem respondidos por completo. Há também a limitação em relação à divulgação do questionário via online, o que provoca a ausência da pesquisadora, que não pode explicar ou esclarecer as possíveis dúvidas dos participantes.

O questionário não permite ainda que se conheçam, em profundidade, os itens abordados nem as questões pessoais dos indivíduos, o que permitiria a diminuição de possíveis distorções e entenderia melhor o momento de carreira da pessoa.

Todavia, apesar de tais limitações, este estudo atendeu aos objetivos esperados, pois conseguiu identificar o que os jovens da Geração $Y$ desejam em termos de carreira, considerando suas âncoras de carreira. 


\section{Descrição e análise dos resultados}

Nesta seção serão apresentadas as informações obtidas a partir do questionário aplicado bem como sua análise com base no referencial teórico abordado neste trabalho. Em seguida, algumas correlações entre os perfis dos respondentes e suas âncoras de carreira serão apresentados.

Ao todo foram obtidas 95 respostas válidas, devido à aplicação de filtros ou a não conclusão do questionário.

\subsection{Perfil dos participantes}

O gráfico 1 apresenta a divisão de faixa etária dos respondentes. As faixas consideradas estão entre 18 e 38 anos, que contempla a Geração Y, de acordo com Veloso et al. (2008). Pode-se perceber uma distribuição assimétrica, pois a maior parte dos respondentes possuem idade entre 18 e 27 anos, o que deve ser considerado na análise dos resultados.

\section{Gráfico 1 - Idade dos participantes}

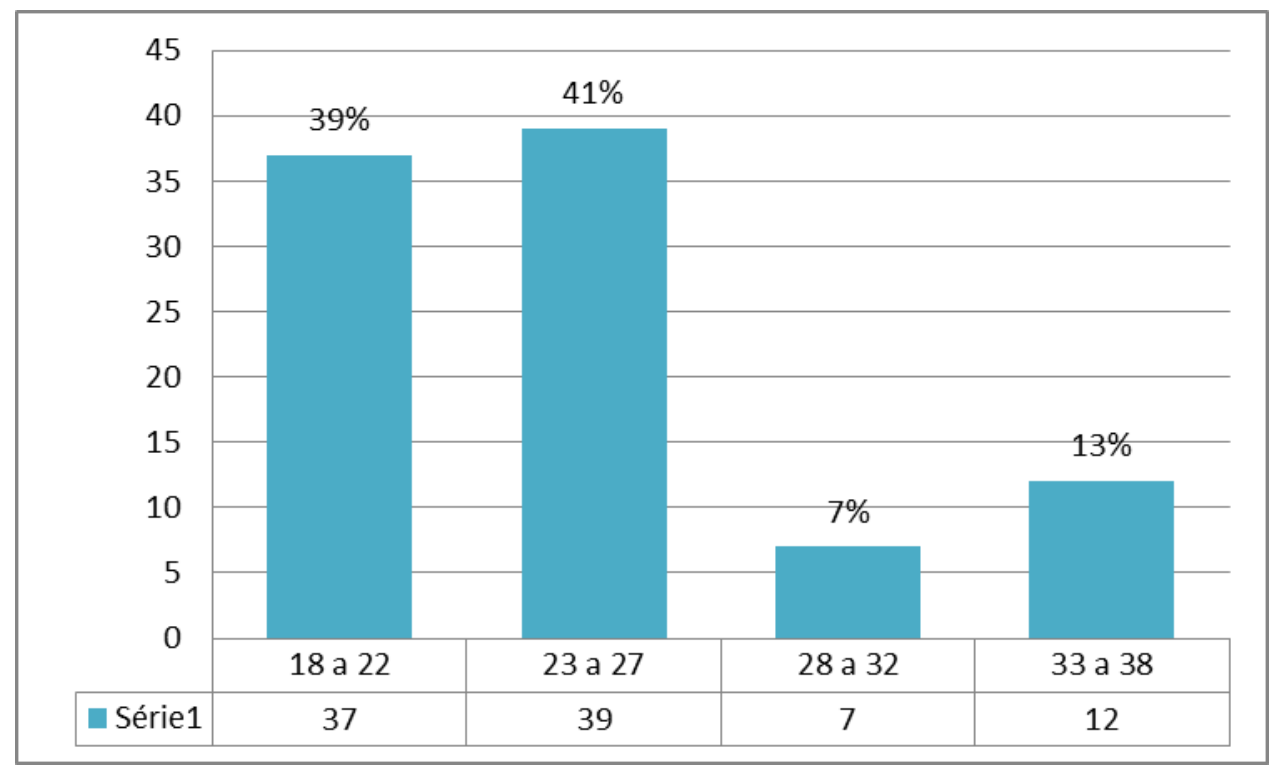

Fonte: Própria Autora (2016) 
A maioria dos participantes foi do sexo feminino contando com $66 \%$, como pode ser visto no gráfico 2 :

\section{Gráfico 2 - Sexo dos participantes}

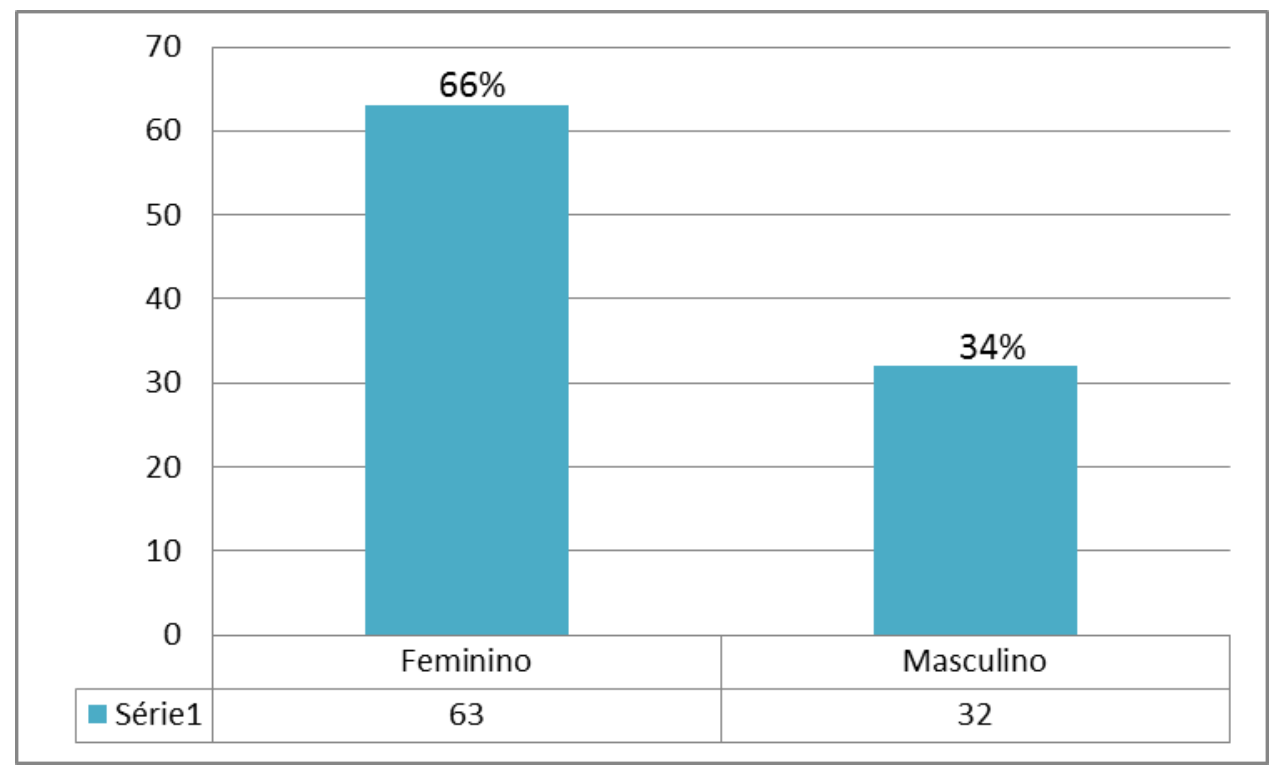

Fonte: Própria Autora (2016)

Os gráficos 3 e 4 demonstram o tipo de moradia e a composição familiar, que são fatores que correspondem à algumas características da Geração Y, pois, de acordo com Lipkin e Perrymore (2010), foram superprotegidos pelos pais, sendo afastados de situações que poderiam desenvolver independência. Como apresentado na tabela 3, a maioria, 61 participantes, ainda mora com os pais, uma diferença considerável em relação aos demais. Apesar das idades variadas, a faixa etária que apresenta a maior porcentagem (51\%), que ainda mora com os pais foi de 23 a 27 anos.

Segundo Lombardia (2008), a Geração Y normalmente é composta por filhos únicos, o que não ocorreu na amostra pesquisa, tal qual ilustrado no gráfico 4.

Tabela 3 - Idade relativa de moradia com pai e/ou mãe

\begin{tabular}{|c|c|c|}
\hline Idade & Qtd. & $\%$ \\
\hline $18-22$ & 26 & $43 \%$ \\
\hline
\end{tabular}




\begin{tabular}{|c|c|c|}
\hline Idade & Qtd. & $\%$ \\
\hline $23-27$ & 31 & $51 \%$ \\
\hline $28-32$ & 3 & $4 \%$ \\
\hline $33-38$ & 1 & $2 \%$ \\
\hline Total & 61 & $100 \%$ \\
\hline
\end{tabular}

Fonte: Própria autora (2016)

\section{Gráfico 3 - Moradia}

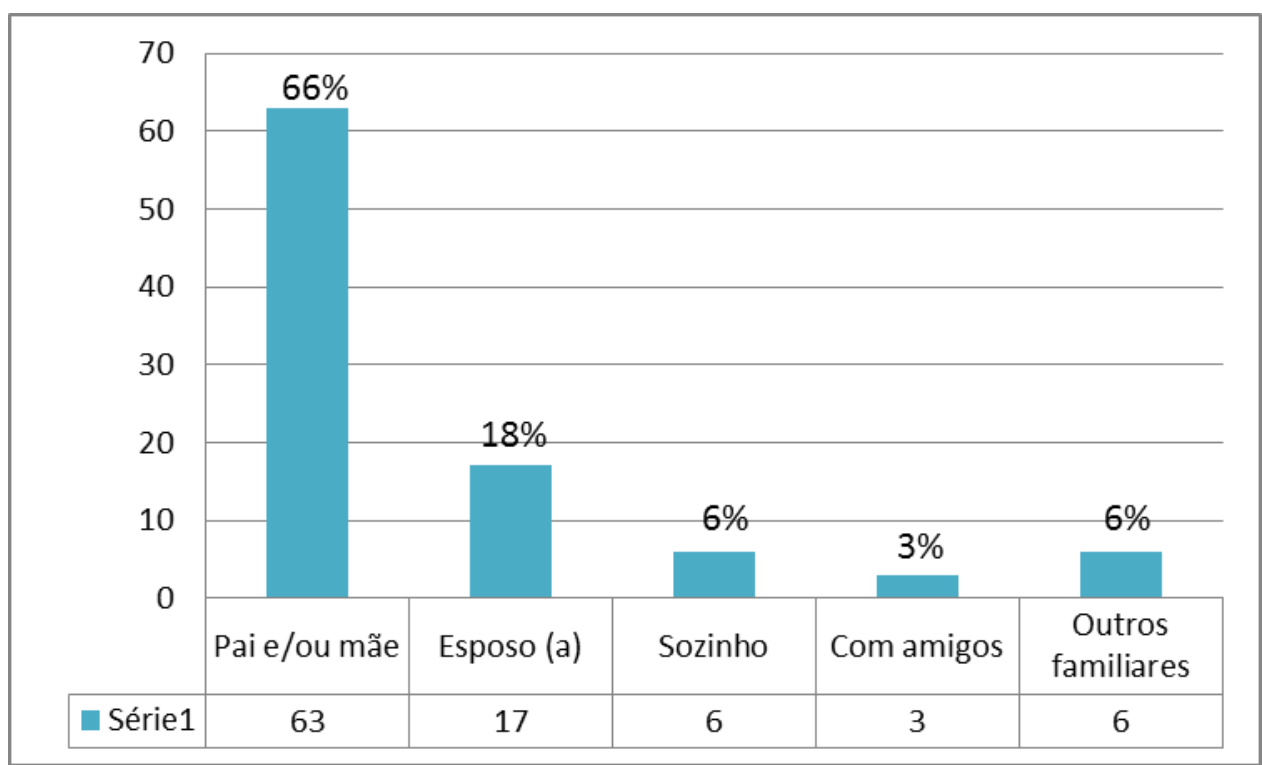

Fonte: Própria autora (2016)

\section{Gráfico 4 - Composição da família}

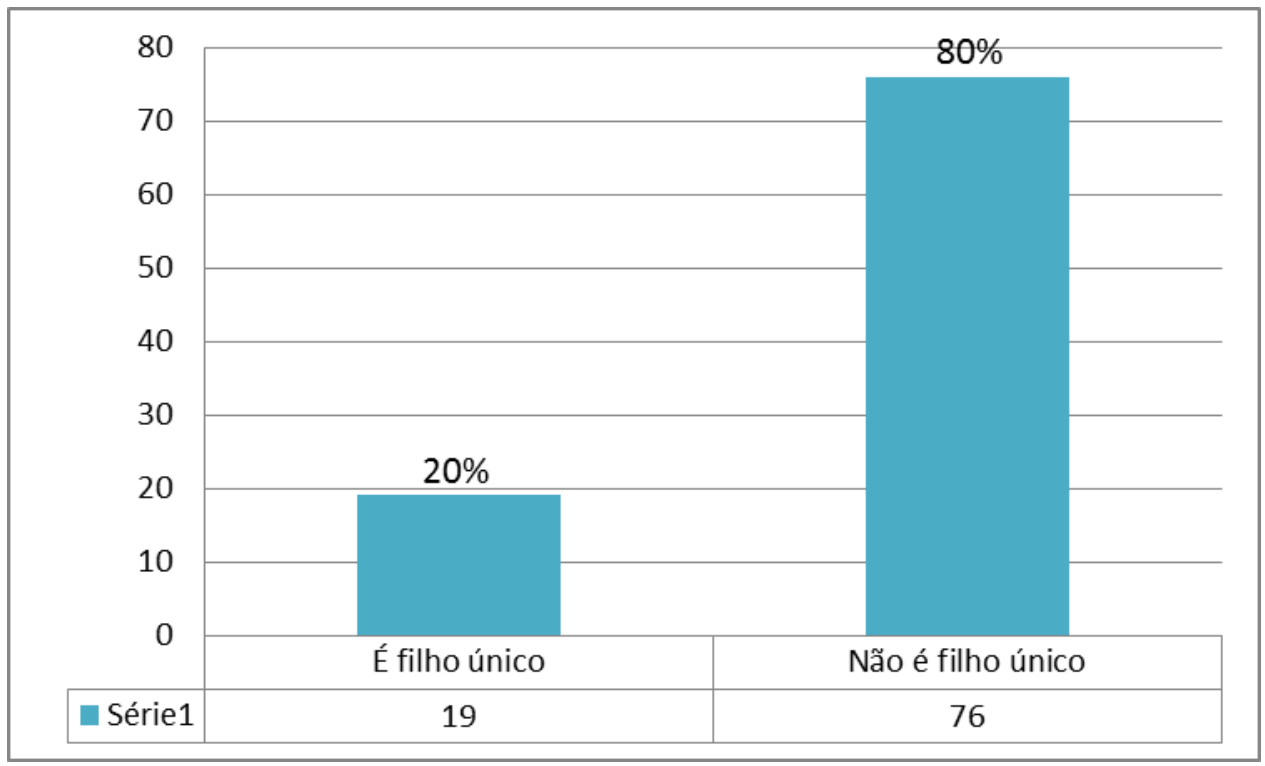

Fonte: Própria autora (2016) 
Já o gráfico 5 representa se os $\mathrm{Y}$ possuem filhos, o que pode influenciar nas âncoras de carreira dos indivíduos, uma vez que possuem responsabilidades e não estão mais sozinhos. A maioria deles não possui filhos, com $83 \%$, o que pode ser explicado pelo fato de a maior parte da amostra possuir idade entre 18 e 27 anos.

\section{Gráfico 5 - Composição da família}

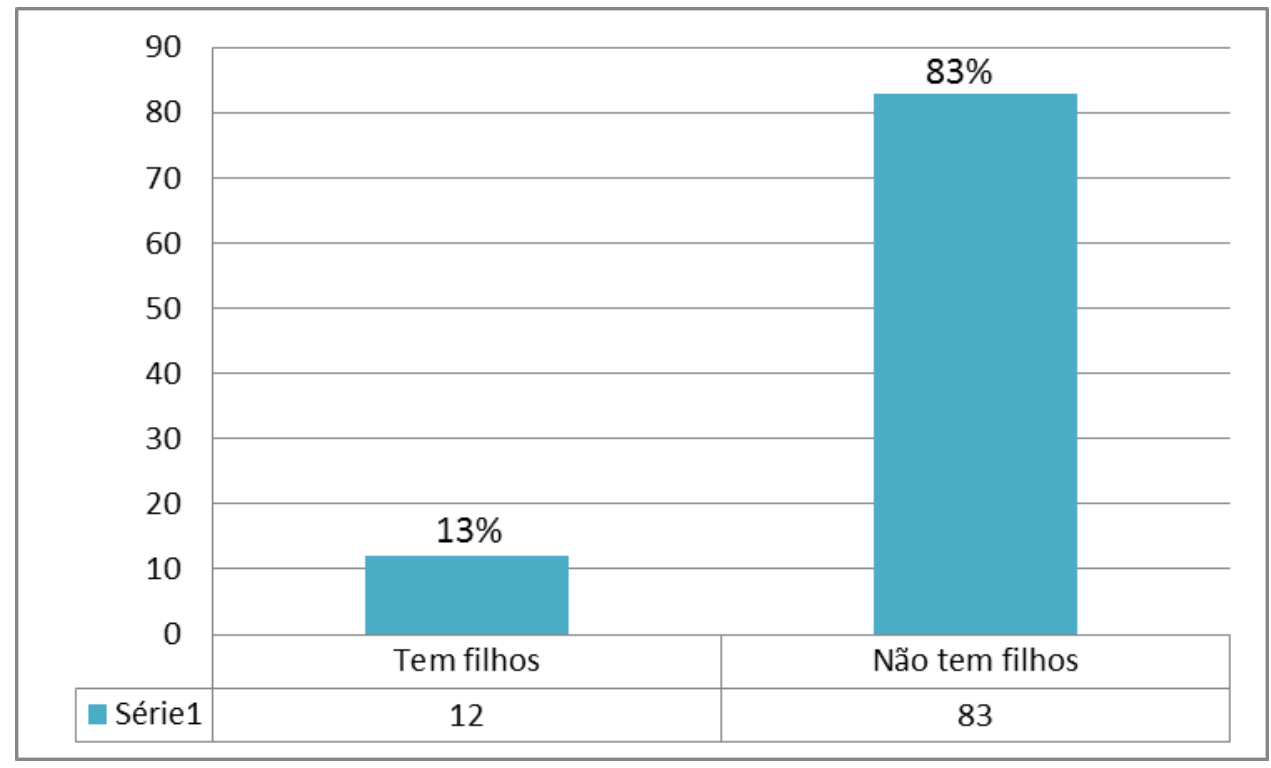

Fonte: Própria autora (2016)

A seguir, no gráfico 6 e tabela 4, são apresentados o nível de escolaridade e local de realização do curso de ensino superior, respectivamente.

Como pode ser observado no gráfico 6 , a maioria dos $Y$ está cursando o Ensino Superior ou já concluíram, sendo que alguns cursam/finalizaram a pós-graduação. Isso é bem característico dessa geração, já que, de acordo com Lipkin e Perrymore (2010), focam em especialização em uma área para conseguirem ser bem reconhecidos pelo o que fazem.

Dentre os locais onde os cursos foram realizados, a maioria (60\%) foi da Universidade PUC-Rio, uma vez sendo o local mais acessível para a autora. 


\section{Gráfico 6 - Grau de escolaridade}

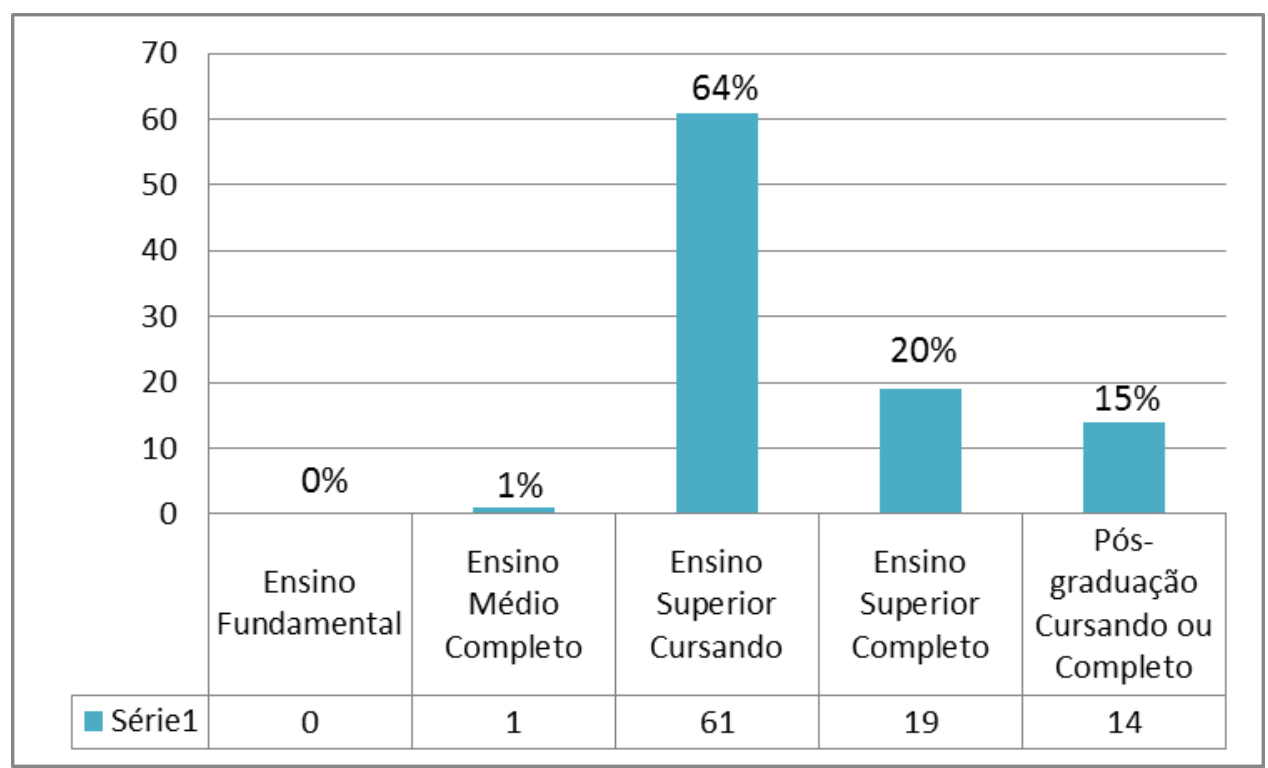

Fonte: Própria autora (2016)

Tabela 4 - Locais cursados no Ensino Superior

\begin{tabular}{|c|c|r|}
\hline Local & Quantidade & \multicolumn{1}{c|}{$\%$} \\
\hline PUC-Rio & 57 & $60,0 \%$ \\
\hline IBMEC & 2 & $2,1 \%$ \\
\hline FGV & 1 & $1,1 \%$ \\
\hline UFRJ & 8 & $8,4 \%$ \\
\hline UERJ & 1 & $1,1 \%$ \\
\hline UFF & 2 & $2,1 \%$ \\
\hline UNIRIO & 1 & $1,1 \%$ \\
\hline UVA & 3 & $3,2 \%$ \\
\hline IBMR & 2 & $2,1 \%$ \\
\hline Estácio & 5 & $5,3 \%$ \\
\hline UCAM & 2 & $2,1 \%$ \\
\hline Outros & 11 & $11,6 \%$ \\
\hline Total & 95 & $100 \%$ \\
\hline
\end{tabular}

Fonte: Própria autora (2016)

O gráfico 7 demonstra a divisão dos participantes por renda familiar. Segundo o IBGE (2016), as classes são divididas pela quantidade da renda familiar recebida, por salários mínimos. A classe $E$ é de até $R \$ 1.760,00$ (2 salários mínimos) e teve $8 \%$ de respostas; classe D de $R \$ 1.760,01$ a $3.720,00$ (2 a 4 salários mínimos) com 19\%; classe C de $R \$ 3.720,01$ a $R \$ 8.800,00$ (de 4 a 10 salários mínimos) sendo a maioria 
com $27 \%$, classe $B$ de $R \$ 8.800,01$ a $R \$ 17.600,00$ (de 10 a 20 salários mínimos) com 23\%; e a classe $A$ é de $R \$ 17.600,01$ ou mais (mais de 20 salários mínimos) representando $22 \%$ do total.

\section{Gráfico 7 - Renda familiar}

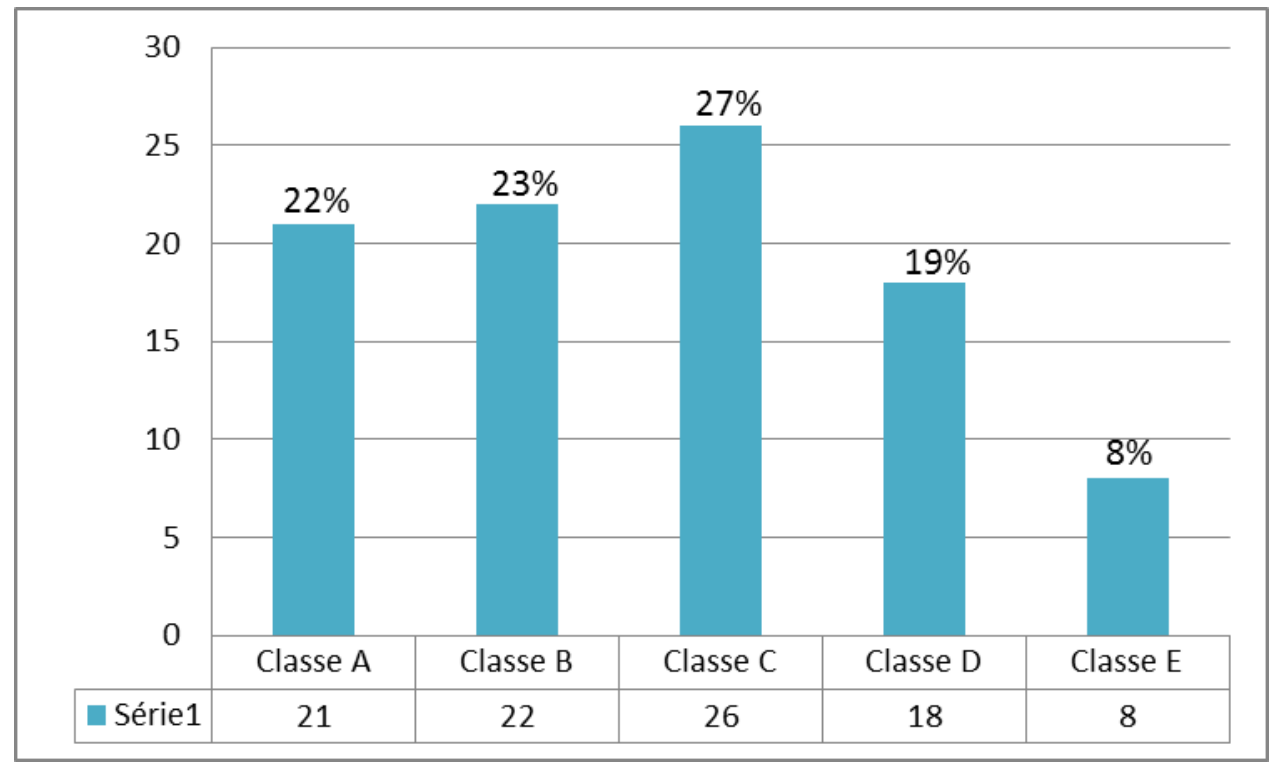

Fonte: Própria autora (2016)

\subsection{Perfil profissional dos participantes}

Para Lipkin e Perrymore (2010), os Y não são considerados fieis às empresas, já que se suas motivações externas e internas não forem atingidas, como ter feedback constante e se não sentirem entusiasmos, eles não se sentem na obrigação de permanecer naquele lugar. Estão em constante busca do trabalho que os satisfazem.

Do total de 95 participantes, $77 \%$ trabalhou entre 1 a 3 empresas e $23 \%$ em 4 ou mais empresas. Os que não ainda não trabalharam foram filtrados para o término da pesquisa. 0 gráfico 8 demonstra as informações. 
Gráfico 8 - Quantidade de empresas trabalhadas

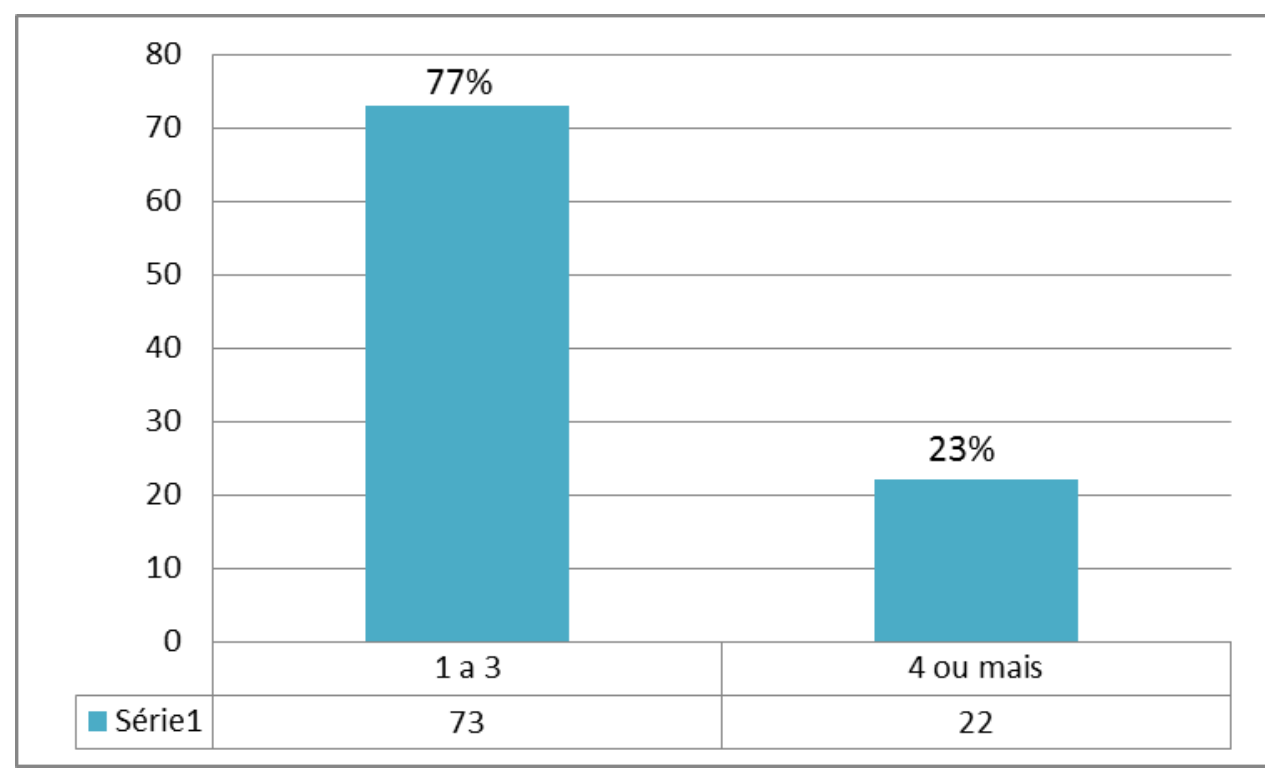

Fonte: Própria autora (2016)

Apresenta-se no gráfico 9 a porcentagem dos respondentes que estão trabalhando atualmente (72\%) e o que não estão (28\%). Para os que estão atuando no mercado, a maioria gostaria de fazer carreira na empresa que está (57\%); os que não gostariam correspondem a $24 \%$ e os que ainda não sabem conta com o total de $19 \%$, como pode ser observado no gráfico 10.

\section{Gráfico 9 - Trabalho atualmente}

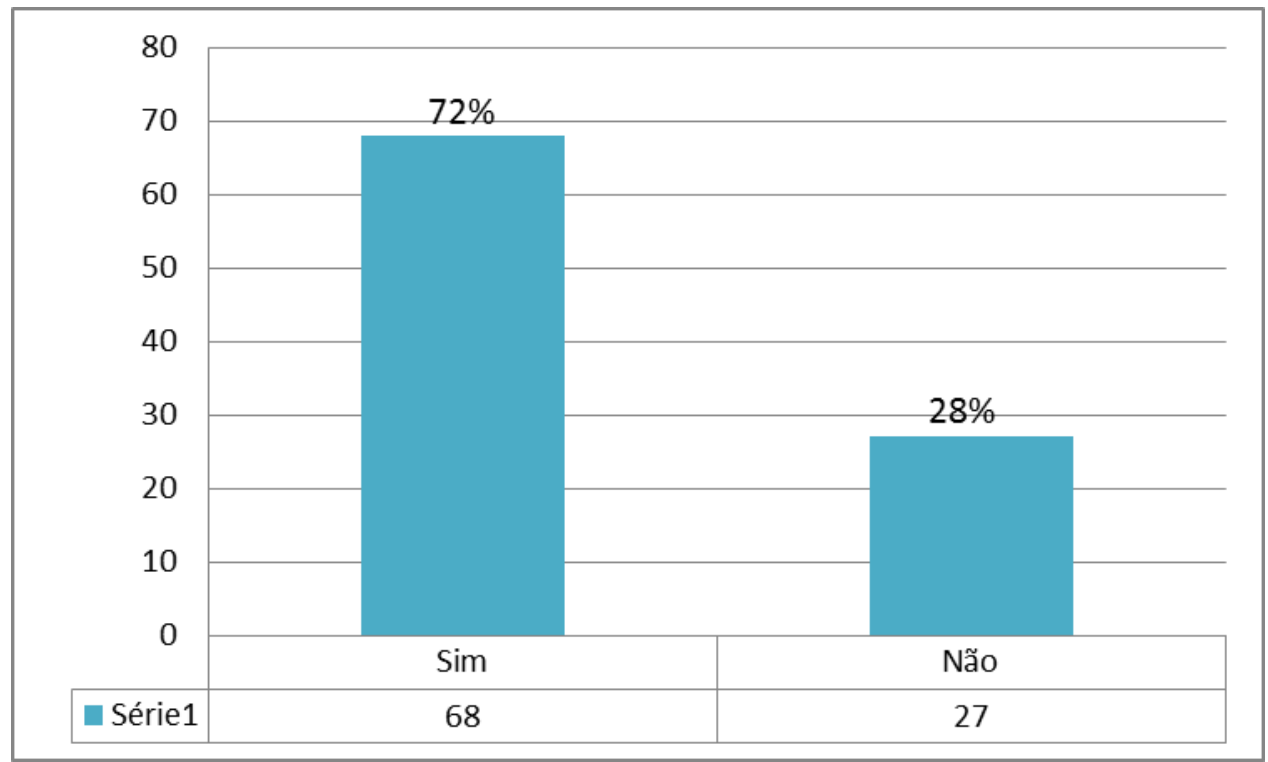

Fonte: Própria autora (2016) 
Gráfico 10 - Fazer carreira na empresa atual

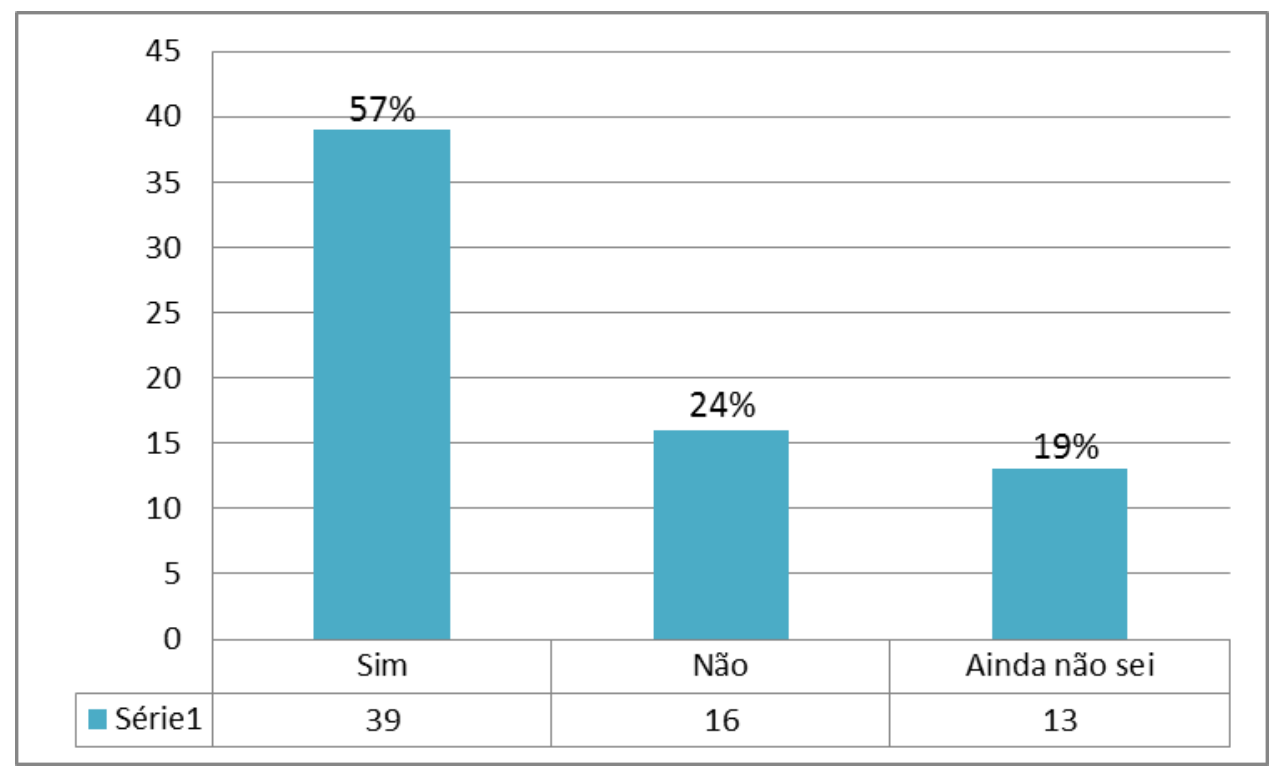

Fonte: Própria autora (2016)

Avaliar a questão de saída da última empresa condiz com o possível comportamento dos Millenials. A tabela 5 mostra os fatores que os incentivaram a sair de alguma de suas experiências profissionais. Os participantes poderiam marcar mais de uma opção e para eles, o principal motivo de saída foi a falta de possibilidade de crescimento. Segundo Oliveira (2009), como gostam de ser flexíveis, não se preocupam em manter a lealdade na empresa.

Tabela 5 - Motivos de saída da empresa

\begin{tabular}{|l|r|r|}
\hline Qual foi o motivo de saída da ultima empresa? & Qtd. & \multicolumn{1}{|c|}{$\%$} \\
\hline $\begin{array}{l}\text { Problemas de relacionamento com gestor e/ou colegas de } \\
\text { trabalho }\end{array}$ & 9 & $7 \%$ \\
\hline Ambiente de trabalho desagradável & 18 & $14 \%$ \\
\hline Sem possibilidade de crescimento & 36 & $27 \%$ \\
\hline Insatisfação com salários e benefícios & 12 & $9 \%$ \\
\hline Não conseguia conciliar vida profissional com pessoal & 8 & $6 \%$ \\
\hline Essa é a primeira experiência & 10 & $8 \%$ \\
\hline Conseguiu outra oportunidade melhor & 19 & $14 \%$ \\
\hline Outros & 21 & $16 \%$ \\
\hline TOTAL & 133 & $100 \%$ \\
\hline
\end{tabular}


Fonte: Própria autora (2016)

\section{3.Âncoras de carreira}

Conforme já detalhado, utilizou-se o Inventário de Âncoras de Carreira de Schein (1996), composto por 40 questões para identificar os impulsionadores dos Y. O resultado, por ordem de importância, segue apresentado na tabela 6 .

Em relação à 1a âncora, que é a de representação mais forte dos indivíduos pesquisados, a mais representativa foi o Estilo de Vida, equivalendo a 36\% do total. Segundo Schein (1996), essa âncora condiz com o perfil de conciliação das necessidades pessoais, familiares e carreira. Esse percentual pode ser interpretado considerando Tulgan (2009), uma vez que ele afirma que Geração $Y$ prioriza as questões pessoais às questões profissionais, almejando conseguir equilibrar os dois. Em segundo lugar, apareceu a Âncora Serviço ou Dedicação a uma causa. Alsop (2008), entre outros autores, afirmam que os jovens $Y$ se preocupam com as questões socioambientais. O cuidado com os outros e a consciência sempre fizeram parte de suas vidas. Essa percepção tem feito o trabalho voluntário virar tendência por causa dessa visão socialmente responsável (LIPKIN; PERRYMORE, 2010).

Tabela 6 - Primeira âncora de carreira

\begin{tabular}{|c|c|c|}
\hline \multicolumn{3}{|c|}{ 1a Âncora } \\
\hline Âncora de Carreira & Qtd. & $\%$ \\
\hline Estilo de Vida & 34 & $36 \%$ \\
\hline Serviço e Dedicação a uma causa & 16 & $17 \%$ \\
\hline Segurança e estabilidade & 12 & $13 \%$ \\
\hline Autonomia e Independência & 9 & $9 \%$ \\
\hline Criatividade Empreendedora & 9 & $9 \%$ \\
\hline Desafio Puro & 6 & $7 \%$ \\
\hline Competência Técnico/Funcional & 5 & $5 \%$ \\
\hline Competência Gerencial Geral & 4 & $4 \%$ \\
\hline TOTAL & 95 & $100 \%$ \\
\hline
\end{tabular}

Fonte: Própria autora (2016) 
A âncora escolhida como a segunda mais importante também foi o Estilo de Vida com 28\%, o que só contribuiu para confirmar sua importância. Em seguida aparece Autonomia e Independência (16\%), o que talvez possa a ser interpretado devido ao ambiente tecnológico em que nasceram e também com outras características de seu perfil profissional, já que buscam a liberdade e empregos que permitam a flexibilidade. Não gostam ainda de ser mandados e apreciam trabalhar à sua maneira (TULGAN, 2009; LIPKIN; PERRYMORE, 2010).

Tabela 7 - Segunda Âncora de Carreira

\begin{tabular}{|c|c|c|}
\hline \multicolumn{3}{|c|}{ 2a Âncora } \\
\hline Âncora de Carreira & Qtd. & $\%$ \\
\hline Estilo de Vida & 26 & $28 \%$ \\
\hline Autonomia e Independência & 15 & $16 \%$ \\
\hline Criatividade Empreendedora & 14 & $14 \%$ \\
\hline Serviço e Dedicação a uma causa & 13 & $13 \%$ \\
\hline Segurança e estabilidade & 10 & $11 \%$ \\
\hline Desafio Puro & 8 & $9 \%$ \\
\hline Competência Técnico/Funcional & 6 & $7 \%$ \\
\hline Competência Gerencial Geral & 3 & $3 \%$ \\
\hline TOTAL & 95 & $100 \%$ \\
\hline
\end{tabular}

Fonte: Própria autora (2016)

Para a terceira Âncora de carreira, como mostrado na tabela 8, o primeiro lugar ficou a Competência Técnico/Funcional com $24 \%$ do total. Isso pode ser explicado pelos profissionais $Y$ que buscam a especialização em uma área e novos desafios, pois querem ser reconhecidos por esse domínio de um conhecimento específico (TULGAN, 2009; DETONI et al., 2012). Pode-se perceber também que em segundo lugar, na terceira Âncora, apareceu novamente Serviço ou dedicação a uma causa, já anteriormente explicado.

Tabela 8 - Terceira Âncora de Carreira

\begin{tabular}{|l|c|c|}
\hline \multicolumn{3}{|c|}{ 3a Âncora } \\
\hline \multicolumn{1}{|c|}{ Âncora de Carreira } & Qtd. & $\%$ \\
\hline Competência Técnico/Funcional & 23 & $24 \%$ \\
\hline Dedicação a uma causa & 17 & $18 \%$ \\
\hline
\end{tabular}




\begin{tabular}{|l|c|r|}
\hline \multicolumn{1}{|c|}{ Âncora de Carreira } & Qtd & \multicolumn{1}{c|}{$\%$} \\
\hline Segurança e estabilidade & 16 & $17 \%$ \\
\hline Estilo de Vida & 14 & $14 \%$ \\
\hline Autonomia e Independência & 9 & $9 \%$ \\
\hline Desafio Puro & 6 & $7 \%$ \\
\hline Competência Técnico/Funcional & 5 & $5 \%$ \\
\hline Competência Gerencial Geral & 4 & $4 \%$ \\
\hline TOTAL & 95 & $100 \%$ \\
\hline
\end{tabular}

Fonte: Própria autora (2016)

Por fim, pode-se perceber que o item menos escolhido foi o de Gerência Geral, nas 3 âncoras. Uma interpretação que pode ser dada é que, segundo Tulgan (2009), não é característica dos $Y$ de atingir altas hierarquias da empresa, de liderar, nem de considerar que o sucesso da empresa é seu sucesso próprio.

Optou ainda por realizar um cruzamento entre a classe social dos respondentes e suas âncoras de carreira. Observou, tal qual demonstrado na tabela 9, as classes sociais, que os respondentes de rendas diferentes apresentam, em primeiro lugar, a âncora Estilo de Vida. Já em segundo lugar elas são diferentes umas das outras. Reforça-se assim, a percepção que a âncora Estilo de Vida é a principal da Geração $Y$, independente da classe social, considerando a amostra pesquisada.

Tabela 9 - Classe social e suas principais âncoras

\begin{tabular}{|c|l|}
\hline Classe Social & \multicolumn{1}{c|}{ Principais Âncoras } \\
\hline \multirow{2}{*}{$A$} & 1) Estilo de Vida \\
\cline { 2 - 2 } & 2) Dedicação a uma causa \\
\hline \multirow{2}{*}{$B$} & 1)Estilo de Vida \\
\cline { 2 - 2 } & 2) Dedicação a uma causa \\
\hline \multirow{2}{*}{$C$} & 1) Estilo de Vida \\
\cline { 2 - 2 } & 2) Competência Técnico/Funcional \\
\hline \multirow{2}{*}{$D$} & 1) Estilo de Vida \\
\cline { 2 - 2 } & 2) Segurança e Estabilidade \\
\hline \multirow{2}{*}{$E$} & 1) Estilo de Vida \\
\cline { 2 - 2 } & 2) Criatividade Empreendedora \\
\hline
\end{tabular}

Fonte: Própria autora (2016) 


\section{Conclusão}

O objetivo deste trabalho foi identificar o que os jovens da Geração $Y$ buscam em termo de carreira considerando suas características e as âncoras de carreira, definidas por Schein (1996).

A fim de alcançar 0 objetivo foram realizadas pesquisas bibliográficas e de campo. Primeiramente, apresentaram-se os conceitos da Geração $Y$ e sobre o Inventário das Âncoras de Carreira. Para a realização da pesquisa de campo, utilizou-se um questionário de 12 perguntas fechadas e as 40 perguntas do Modelo de Âncoras de Carreira, para descobrir quais âncoras são as preferidas pelos respondentes. Os dados obtidos com a amostra de 95 pessoas foram tratados quantitativamente e geraram-se gráficos e tabelas que foram interpretadas considerando o referencial teórico adotado.

A partir das informações conquistadas, pode-se considerar que 0 objetivo do trabalho foi atingido, uma vez que foi possível identificar as âncoras de carreiras mais preferidas pela geração Y. A tabela 10 apresenta as âncoras mais selecionadas em ordem de importância.

Tabela 10 - Resultado: Âncoras de Carreira

\begin{tabular}{|l|l|c|}
\hline \multicolumn{3}{|c|}{ Âncoras de Carreira } \\
\hline Ordem & \multicolumn{1}{|c|}{ Âncora } & $\%$ \\
\hline $1^{\text {a }}$ & Estilo de Vida & $36 \%$ \\
\hline $2^{\text {a }}$ & Estilo de Vida & $28 \%$ \\
\hline $3^{\text {a }}$ & Competência Técnico/Funcional & $24 \%$ \\
\hline
\end{tabular}

Fonte: Própria Autora (2016)

A âncora que recebeu maior classificação dentre todas foi a Estilo de Vida, representando $36 \%$ das respostas, o que reflete a vontade dos jovens desta geração em manter em equilíbrio a vida profissional e a pessoal, o que reflete uma das principais características da Geração Y. Buscam trabalhos que atendam a essas necessidades. A citada âncora 
também apareceu em segundo lugar. Em terceiro, a âncora mais selecionada foi a Competência Técnico/Funcional com $24 \%$, o que pode demonstrar a vontade desses jovens de se especializarem em certa área e possuírem bastante conhecimento sobre aquilo, já que os Millennials cobiçam ser reconhecidos por suas habilidades técnicas.

A âncora menos representada foi a Competência Gerencial Geral com $4 \%$, o que enfatiza a questão de não terem vontade de chegar à altas hierarquias nem de liderarem, como diferente dos $\mathrm{Y}$, faz parte da natureza das gerações anteriores.

Em relação à comparação das âncoras com as respectivas classes, é possível perceber que, em primeiro lugar, prevaleceu a âncora Estilo de Vida em todas. Em segundo lugar, para as classes A e B, apareceu a âncora Dedicação a uma Causa, que mostra uma maior conscientização social; classe C com Competência Técnico-Funcional; D com Segurança e Estabilidade, o que é compreensível pois possuem uma renda baixa; e a classe E com Criatividade Empreendedora, podendo ser explicado pela possível possibilidade de ascenderem mais rápido abrindo um negócio próprio. Deve-se considerar, contudo, que a quantidade de respondentes em cada uma das classes foi bem diversificado.

Considerando as características que foram expostas em relação à geração $Y$ e, relacionando-as com as âncoras de carreiras mais selecionadas (Estilo de Vida e Competência técnica/funcional), pode-se supor que os jovens buscam oportunidades em que possam se satisfazer com a carreira, equilibrando o lado pessoal e profissional e que desejam se desenvolver tecnicamente em uma área.

\subsection{Sugestões e recomendações para novos estudos}

Este estudo buscou identificar as principais âncoras de carreira dos profissionais da Geração Y.

Recomenda-se que seja realizada uma pesquisa com uma maior amostra para apurar, de fato, se os resultados representam uma maioria e avaliar se as âncoras seriam as mesmas em um universo maior, com uma maior quantidade de respondentes de classes de renda diferenciadas. 
Sugere-se também aplicar entrevistas nos $Y$ para compreender melhor os fatores que levam às tais âncoras escolhidas, bem como estudar as motivações dos jovens em relação às suas empresas atuais. 


\section{Referências Bibliográficas}

ALSOP, R.The trophy kids grow up: How the Millennial Generation is shaking up the workplace. EUA: Jossey-Bass, 2008.

ARTHUR, M., \& ROUSSEAU, D. (1996). A new career lexicon for the 21st century. The Academy of Management Executive, 10(4),28-39.

BALASSIANO, M.; COSTA, I. S. A. Gestão de Carreiras: Dilemas e Perspectivas. São Paulo: Atlas, 2006.

BALASSIANO, M.; VENTURA, E. C. F.; FONTES FILHO, J.R. Carreiras e cidades: existiria um melhor lugar para se fazer carreira?. Revista de

Administração Contemporânea. v. 8, n. 3, p. 99-116, 2004

BERGAMINI, H. Gestão de Carreiras: As cinco ferramentas essenciais. São Paulo: Évora, 2014.

BRISCOE, J.P.; HALL, D.T. The interplay of boundaryless and protean careers:

Combinations and implications. Journal of Vocational Behavior. v,69, n. 1, p. 418, 2006.

BRISCOE, J.P.; HALL, D.T.; DeMUTH, R. L. F. Protean and boundaryless careers: An empirical exploration. Journal of Vocational Behavior. v,69, n. 1, p. 30-47, 2006.

COSTA, L. A relação entra a percepção de sucesso na carreira e o comportamento organizacional: um estudo entre professores de universidades privadas selecionadas da Grande São Paulo. Dissertação de Mestrado em Administração. São Paulo: USP, 2011

DETONI, D.; MARTINS, J.; HARTMANN, D. A importância do autogerenciamento da carreira para geração $Y$ no contexto atual. In: IX SIMPÓSIO DE EXCELÊNCIA EM GESTÃO E TECNOLOGIA, Rio de Janeiro, 2012

GIL, A, C. Métodos e técnicas de pesquisa social. 5 ed. São Paulo: Atlas, 2007 HALL, D. T. Careers in and out of organizations. Sage Publication. California, 2002. 
. Career Indecision Research: Conceptual and Methodological Problems. Journal of Vocational Behavior, v. 41, p. 245-250, 1992.

HALL, D.T.; MOSS, J.E. The new protean career contract: helping organizations and employees adapt. Organizational dynamics, v.26, n.3, p.22-36, 1998. INSTITUTO BRASILEIRO DE GEOGRAFIA E ESTATÍSTICA. Ministério do Planejamento, Orçamento e Gestão, 2016. Disponível em: <www.ibge.gov.br/estatistica/populacao/trabalhoerendimento $>$. Acesso em: 28 set. 2016.

KILIMNIK, Z. M.; CASTILHO, I. V.; SANT'ANNA, A. S. Carreiras em transformação e seus paradoxais reflexos nos indivíduos: Metáforas de carreira e de competências. Comportamento Organizacional e gestão. v,12, n. 2, p. 257280, 2006

et al. Estilo de Vida e Segurança: seriam essas as âncoras do futuro detentores de carreiras proteanas ou sem fronteiras? Um estudo comparativo entre alunos de graduação e de Mestrado em Administração. IV Convibra, 2007. Disponível em: < http://www.convibra.com.br/artigo.asp?ev=25\&id=2027>. Acesso em: 29 set. 2016.

KUPPERSCHMIDT, B. R. Multigeneration employees: strategies for effective management. The Health Care Manager, v. 19, n. 1, p. 65-76, 2000.

LIPKIN, N.; PERRYMORE, A. A Geração Y no trabalho: Como lidar com a força de trabalho que influenciará definitivamente a cultura da sua empresa. Tradução de Bruno Alexandre. Rio de Janeiro: Elsevier, 2010.

LOMBARDÍA, P. G.; STEIN, G.; RAMÓ N PIN, J. Quem é a geração Y?.HSM Management, São Paulo, v. 3, n. 70, set./out. 2008.

MELO, G. Construção de uma carreira bem sucedida: o que querem as mulheres da Geração Y?. Rio de Janeiro, 2010. 58 p. Trabalho final de cursos (Disciplina Integradora IV) - Departamento de Administração: Pontifícia Universidade Católica do Rio de Janeiro.

OLIVEIRA, S. Geração Y: Era das conexões - Tempo dos Relacionamentos. São Paulo: Clube dos Autores, 2009.

. Geração Y: O nascimento de uma nova versão de líderes. São Paulo: Integrare Editora, 2010. 
SCHEIN, E. H. Career Dynamic: Matching individual and organizational needs. Massachusetts: Addison-Wesley, 1978.

Identidade Profissional: Como ajustar suas inclinações a suas opções de trabalho. Tradução de Margarida D. Black. São Paulo: Nobel, 1996.

SILVA, G. Psicologia aplicada à administração. São Paulo: Elsevier, 2011. SMOLA, K. W; SUTTON, C. D. Generational Differences: Revisiting Generational Work Values for the New Millenium. Journal of Organizational Behavior, v.23, p. 363-382, 2002.

SOLOMON, M. R. O comportamento do consumidor: comprando, possuindo e sendo. Tradução de Beth Honorato. Porto Alegre: Bookman, v.11, 2016.

TULGAN, B. Not everyone gets a trophy: How to manage Generation Y. EUA: Jossey-Bass, 2009.

TWENGE, J. M.; CAMPBELL, S. M. Generational differences in psychological traits and their impact on the workplace. Journal of Managerial Psychology, v.23, n. 8, 2008.

VELOSO, E. F. R.; DUTRA, J. S.; NAKATA, L. E. Percepções sobre carreiras inteligentes: diferenças das gerações $\mathrm{X}, \mathrm{Y}$ e baby boomers. In: ENCONTRO NACIONAL DE PROGRAMAS DE PÓS-GRADUAÇÃO EM ADMINISTRAÇÃO, 2008, Rio de Janeiro/RJ: ANPAD, 2008.

VERGARA, S.; Projetos e relatórios de pesquisa em Administração. São Paulo: Atlas, 2004.

WONG, M.; GARDINER, E; LANG, W. COULON, L.. Generational differences in personality and motivation. Do they exist and what are the implications for the workplace? Journal of Managerial Psychology, v. 23, n.8, 2008. 


\section{Apêndice 1}

Olá, sou a Fernanda, aluna de graduação de Administração da PUC-Rio. Gostaria que você respondesse esse questionário que faz parte da minha monografia de conclusão do curso.

Ele não demorará mais que 10 minutos. Peço que responda com honestidade, e as questões serão confidenciais.

O prazo para que o questionário seja respondido é até 12/11/2016.

Quaisquer dúvidas que tenha, meu email é fefeconti28@hotmail.com.

Agradeço a participação!

Qual a sua idade?

- 18 a 22

- 23 a 27

- 28 a 32

- 33 a 38

Em quantas empresas já trabalhou?

- Nenhuma

- De 1 a 3

- 4 ou mais

\section{Âncoras de Carreira}

Você vai encontrar a seguir, um conjunto de 40 afirmações. Atribua a cada uma delas um valor de 1 a 6 conforme:

O que a frase afirma NUNCA é verdadeiro para mim: 1

O que a frase afirma OCASIONALMENTE é verdadeiro para mim: 2 (menor intensidade) ou 3 (maior intensidade)

$O$ que a frase afirma FREQUENTEMENTE é verdadeiro para mim: 4 (menor intensidade) ou 5 (maior intensidade)

O que a frase afirma SEMPRE é verdadeiro para mim: 6

1. Sonho em ser tão bom no que faço, de tal forma que meus conhecimentos especializados sejam constantemente procurados 
2. Sinto-me mais realizado em meu trabalho quando sou capaz de integrar e gerenciar o esforço dos outros

3. Sonho em ter uma carreira que me dê a liberdade de fazer o trabalho à minha maneira e no tempo por mim programado

4. Segurança e estabilidade são mais importantes para mim do que liberdade e autonomia

5. Estou sempre procurando ideias que me permitam iniciar meu próprio negócio

6. Sinto-me bem em minha carreira apenas quando tenho a sensação de ter feito uma contribuição real para o bem da sociedade

7. Sonho com uma carreira na qual eu possa solucionar problemas ou vencer inúmeras situações desafiadoras

8. Preferiria deixar meu emprego do que ser colocado em um trabalho que comprometesse minha dedicação a assuntos pessoais e 0 familiares

9. Sinto-me bem sucedido em minha carreira apenas quando posso desenvolver minhas habilidades técnicas com grande competência

10. Sonho em dirigir uma organização complexa e tomar decisões que afetem muitas pessoas

11. Sinto-me mais realizado em meu trabalho quando tenho total liberdade para definir minhas tarefas, horários e procedimentos

12. Preferiria deixar meu emprego do que aceitar uma tarefa que colocasse em risco minha segurança na organização

13. Montar meu próprio negócio é mais importante para mim do que atingir uma alta posição gerencial como empregado

14. Sinto-me mais realizado em minha carreira quando posso utilizar meus talentos a serviço dos outros

15. Sinto-me realizado em minha carreira apenas quando enfrento e supero desafios extremamente difíceis

16. Sonho com uma carreira que me permita integrar minhas necessidades pessoais, familiares e de trabalho

17. Tornar-me um gerente técnico em minha área de especialização é mais atraente para mim do que tornar-me um gerente geral 
18. Vou me sentir bem sucedido em minha carreira apenas quando me tornar um gerente geral em alguma organização

19. Vou me sentir bem sucedido em minha carreira apenas quando alcançar total autonomia e liberdade

20. Procuro trabalho em organizações que me dêem senso de segurança e estabilidade

21. Sinto-me realizado em minha carreira quando tenho a oportunidade de construir algo que seja resultado de minhas próprias ideias e esforços

22. Contribuir com minhas habilidades para um mundo melhor para se viver e trabalhar é mais importante do que alcançar um alto posto gerencial

23. Sinto-me mais realizado em minha carreira quando soluciono problemas insolúveis ou venço o que era aparentemente invencível

24. Sinto-me bem sucedido na vida quando sou capaz de equilibrar minhas necessidades pessoais, familiares e de carreira

25. Preferiria deixar meu emprego do que aceitar um rodízio de tarefas que me afastasse de minha área de experiência

26. Me tornar um gerente geral é mais atraente para mim do que ser um gerente técnico em minha área de especialização

27. Para mim, poder fazer um trabalho à minha própria maneira, sem regras e restrições, é mais importante do que segurança

28. Sinto-me mais realizado em meu trabalho quando percebo que tenho total segurança financeira e estabilidade no trabalho

29. Sinto-me bem sucedido em meu trabalho apenas quando posso criar ou construir alguma coisa que seja inteiramente de minha autoria

30. Sonho em ter uma carreira que traga uma real contribuição à sociedade e à humanidade

31. Procuro oportunidades de trabalho que desafiem fortemente minhas habilidades para solucionar problemas

32. Equilibrar as exigências da minha vida pessoal e profissional é mais importante do que alcançar alta posição gerencial

33. Sinto-me plenamente realizado em meu trabalho quando sou capaz de empregar minhas habilidades e talentos especiais 
34. Preferiria deixar minha empresa do que aceitar um posto de trabalho que me afastasse da trajetória de gerência geral

35. Preferiria deixar minha empresa do que aceitar um posto de trabalho que reduzisse minha autonomia e liberdade

36. Sonho com uma carreira que me dê senso de segurança e estabilidade

37. Sonho com montar meu próprio negócio

38. Preferiria deixar minha empresa do que aceitar uma tarefa que prejudicasse minha capacidade de servir aos outros

39. Trabalhar em problemas praticamente insolúveis para mim é mais importante do que alcançar uma posição gerencial de alto nível

40. Sempre procurei oportunidades de trabalho que não atrapalhasse assuntos pessoais e familiares

Por favor, no final reveja suas respostas acima e localize as que você atribuiu 5 ou 6 . Dentre estas, selecione TRÊS (3) afirmativas que você considera mais importantes e escreva os respectivos números no espaço abaixo.

Sexo?

○ Feminino

- Masculino

Com quem mora?

- Pai e/ou mãe

- Esposo (a)

- Sozinho

- Com amigos

- Outros familiares

É filho único?

- Sim

- Não 
Tem filhos?
○ Sim
○ Não

Nível de escolaridade?

- Ensino Fundamental

- Ensino Médio

- Ensino Superior Cursando

- Ensino Superior Completo

- Pós-graduação cursando ou completo

Qual local cursou graduação?
- PUC-Rio
- IBMEC
○ UFRJ
○ UERJ
○ FGV
- Outra

Esta trabalhando ou estagiando atualmente?
- Sim
○ Não

Gostaria de fazer carreira nessa empresa/profissão?
○ Sim
○ Não
- Ainda não sei

Gosta de onde trabalha?
- Sim
○ Não - Porquê?

Se não gosta de onde trabalha, porque ainda está nele?

- Estou procurando outro 
- Pelo dinheiro

- Pela oportunidade de carreira

- Outros

Qual foi o motivo de saída da empresa? (Pode selecionar mais de uma resposta)

- Problema de relacionamento com gestor e/ou colegas de trabalho

- Ambiente de trabalho desagradável

- Sem possibilidade de crescimento

- Insatisfação com salário e benefícios

- Não conseguia conciliar vida profissional com vida pessoal

- Essa é a minha primeira experiência

- Conseguiu outra melhor oportunidade de trabalho

○ Outros

Qual a sua renda familiar?

○ até $R \$ 1.760$ (até 2 salários mínimos )

- de $\mathrm{R} \$ 1.760,01$ a $\mathrm{R} \$ 3.720,00$ (2 a 4 salários mínimos)

○ de $R \$ 3.720,00$ a $R \$ 8.800,00$ (de 4 a 10 salários mínimos)

○ de $R \$ 8.800,01$ a $R \$ 17.600,00$ (de 10 a 20 salários mínimos)

- de $R \$ 17.600,01$ ou mais (mais de 20 salários mínimos) 